Article

\title{
Techno-Economic Analysis of Solar Tower Aided Coal-Fired Power Generation System
}

\author{
Yong Zhu ${ }^{1, *}$ (D), Rongrong Zhai ${ }^{1}$, Yongping Yang ${ }^{1}$ and Miguel Angel Reyes-Belmonte ${ }^{2}$ \\ 1 School of Energy, Power and Mechanical Engineering, North China Electric Power University, \\ Beijing 102206, China; zhairongrong01@163.com (R.Z.); ncepuyyp@163.com (Y.Y.) \\ 2 IMDEA Energy Institute, Ramon de la Sagra 3, 28935 Móstoles, Spain; miguelangel.reyes@imdea.org \\ * Correspondence: zhuyongvip@gmail.com; Tel.: +86-10-89181221
}

Received: 16 July 2017; Accepted: 1 September 2017; Published: 14 September 2017

\begin{abstract}
In this paper, we conduct a techno-economic analysis of a 1000 MWe solar tower aided coal-fired power generation system for the whole life cycle. Firstly, the power output (from coal and solar thermal energy) under variable direct normal irradiance and grid demand are studied. Secondly, a financial assessment is performed, including profits and losses of the plant project. Thirdly, sensitivity analysis is taken on some external factors that can affect the cost or profits and losses of the plant project. The results indicate that the project has high profits with an internal rate of return (IRR) of $8.7 \%$. In addition, the effects of solar tower field cost, power purchase agreement (PPA) price of solar thermal electricity, coal price, and the interest rate of debt on the main criteria decrease gradually. Therefore, it is better to improve solar tower technology first, and then look for low-interest debts from banks to cope with the reduction of PPA price of solar thermal electricity and the increase of coal price. Despite the introduction of solar tower field increasing levelized cost of electricity (LCOE), it contributes to the reduction of $\mathrm{CO}_{2}$ capture cost compared to the case of standard coal-fired power plants.
\end{abstract}

Keywords: solar tower field; coal-fired power generation system; techno-economic analysis; levelized cost of electricity

\section{Introduction}

Coal-fired power generation is the most common method of power generation in China. By the end of 2014, the electricity generated by coal accounted for $70.5 \%$ of all electricity produced in China [1]. At present, despite desulfurization and denitrification equipment having been installed in coal-fired power plants in China, the long history of coal consumption has led to serious environmental problems. Therefore, it is extremely important for China to optimize electricity production, to innovate on generation technologies, and to increase the proportion of power generated by non-fossil fuels [2,3]. Solar thermal power plants with an energy storage system of sufficient capacity can generate electricity in a stable manner under variable direct normal irradiance (DNI). Therefore, solar thermal power generation is seen as one of the most promising technologies for non-fossil energy power generation [4-6]. At present, China's solar thermal power generation industry is still in its early stages, while the development of related industries is not yet mature. Furthermore, the promotion of the technology in China is limited by the high cost of solar thermal power plants $[7,8]$. If solar thermal fields are coupled with coal-fired power plants, the cost of solar thermal fields and $\mathrm{CO}_{2}$ emission can be reduced by sharing power generation systems and heat recovery systems [9]. Moreover, the high temperature and pressure and large capacity of coal-fired power plants can help to reduce fluctuations in solar thermal power generation, cut the capacity of energy storage system, and improve the utilization efficiency of solar thermal energy [10-12]. This technology of hybrid power generation 
systems is also in line with Chinese policy promoting hybrid solar-wind-coal energy power generation systems [13].

Many researchers have conducted in-depth studies on solar tower aided coal-fired power generation system (STCG). As early as 1975, Zoschak et al. [14] first proposed the concept of hybrid power generation by solar thermal energy and fossil fuel. Seven feasible hybridization methods of solar thermal energy and coal were proposed and applied to an 800 MWe coal-fired power plant, and then the feasibility of these methods was analyzed. Thereafter, Ying and Hu et al. $[9,15,16]$ studied the thermodynamic characteristics of a solar-aided Rankine cycle system and applied this technology to the No. 3 unit of Loy Yang plant. The study showed potential advantages of the coupled system, which generated 30\% more electricity by replacing extracted steam with solar thermal energy. Yang et al. $[17,18]$ first studied parabolic trough solar aided coal-fired power generation systems in China, and proposed optimal integration schemes through simulation, calculation, and assessments of the coupled systems. Based on these studies, Zhai et al. [19-21] made some exergy analyses and optimization under off-design operation conditions on solar fields and energy storage systems of 600 and 1000 MWe parabolic trough solar aided coal-fired power generation systems.

Apart from thermodynamic studies, many researchers analyzed the solar aided coal-fired power plants from other points of view, such as environmental, economic, etc. Suresh et al. [22] made a 4-E's (Energy, Exergy, Environment, and Economic) analysis of solar thermal aided coal-fired power plants, resulting in 14-19\% instantaneous fuel saving and 65,000 $\mathrm{t} \mathrm{CO}_{2}$ emission reduction over a 660 MWe supercritical plant when all extracted steams were cut off. Zhai et al. [23] performed a thermo-economic study of parabolic trough solar aided coal-fired power generation system resulting in $16.9-21.6 \%$ increase on levelized cost of electricity (LCOE) and $15.04 \mathrm{~g} / \mathrm{kWh}$ reduction on coal consumption rate. Feng et al. [24] proposed a thermo-economic evaluation method based on the generalized steam-water distribution matrix equation and applied this method on a 600 MWe of solar aided power generation system, proving the applicability of the method. Wang and Liu et al. [25,26] analyzed a 300 MWe parabolic trough solar aided coal-fired power generation system, and the results show that integrating solar energy with post-combustion $\mathrm{CO}_{2}$ capture can effectively increase power output and reduce the cost of $\mathrm{CO}_{2}$ capture.

The studies above showed the advantages of parabolic trough solar aided coal-fired power generation systems in solar thermal utilization, economic benefits (compared with parabolic trough solar thermal power plants), and environmental benefits. However, few researchers have paid attention to STCG. Among them, Ozturk et al. [27] performed a thermodynamic assessment of an integrated solar power tower and coal gasification system, and carried out a sensitivity analysis on some thermodynamic parameters (such as thermal efficiency and exergy efficiency). Zhang et al. [28] combined solar tower field with boiler by heating superheated steam or sub-cooled water with solar tower thermal energy, and achieved a significant reduction on coal consumption rate $(17 \mathrm{~g} / \mathrm{kWh})$. Zhu et al. [29] performed exergy and advanced exergetic analysis on STCG, and studied the inner exergy stream distribution of the system, the exergy efficiency of each component, and the exergy destruction composition.

Despite the fact that above mentioned studies were focused onto STCG power plant thermal characteristics, detailed economic studies have not been addressed yet. In this paper, a $1000 \mathrm{MWe}$ STCG is adopted for techno-economic analysis over the full life cycle of the plant.

Firstly, STCG is operated under off-design conditions during the whole life cycle due to the changes of direct normal irradiance and grid demand. Later total power output, power output from solar thermal energy and coal, are figured out by solar contribution method.

Secondly, the economic characteristics of solar tower aided coal-fired power plant project are studied by relevant criteria (net present value (NPV), IRR, etc.).

Finally, considering solar multiple, PPA price of electricity from solar thermal energy, plant investment, and coal price, a sensitivity analysis is conducted to study the impacts on the main economic criteria by external factors. 
This study could be used as a starting point for solar-tower-aided coal-fired power plant project planning.

\section{Methodology}

\subsection{Electricity Generation}

Revenue from selling electricity is the main income of solar tower aided coal-fired power plant project and therefore, power output calculation can affect income assessment of the project.

STCG power output consists of two parts, namely electricity generated by the solar tower field and coal-fired power generation systems. Due to the indirect generation of solar thermal energy in STCG, the total power output should be distinguished according to different energy sources. In this paper, solar contribution method described in the literature [30,31] has been used to evaluate the power output from solar tower thermal energy and coal.

Solar contribution is defined as the proportion of electricity (generated with solar thermal energy) to the total amount of power generated by the STCG. The solar contribution method is based on the second law of thermodynamics and thermo-economic theories, and can overcome some shortcomings of traditional evaluation methods by taking energy quality into consideration, and it is suitable for both power boosting and fuel saving modes [18]. Therefore, this solar contribution evaluation method is taken to study STCG in this paper.

\subsection{Financial Models}

Financial assessment of plant project can pre-judge the direct and indirect economic benefits to some extent providing investors bases for decision making.

In this section, the financial models are first introduced from electricity prices and two perspectives (cost and income); then some static and dynamic indicators are explained with or without consideration of the time value of money.

\subsubsection{Electricity Price}

Electricity feed-in tariff plays a key role in the revenue of a plant. In China, there are four main pricing mechanisms: case-by-case pricing, benchmark pricing, average pricing of a local province, and bidding pricing [32].

Coal with $5000 \mathrm{kcal} / \mathrm{kg}$ lower heating value (LHV) is taken as the base coal. When the difference between the price of electricity coal and the base coal is no bigger than CNY 30/t, the policy of coal-electricity price linkage will not be activated and the changes in cost is undertaken by plants owners; when the difference is bigger than $\mathrm{CNY} 30 / \mathrm{t}$, the policy will be activated according to the changed part of the price.

The calculation of the policy of coal electricity price linkage is

$$
P_{\Delta}=C_{\Delta} \cdot C_{i} \times 7000 / 5000 / 10,000
$$

where, $P_{\Delta}$ is the adjustment of electricity price for coal-fired power plants at current stage; $C_{\Delta}$ is the changed price after considering the coefficient of co-movement at the last stage; $C_{i}$ is the standard coal consumption rate at the last stage (for example last year). The standard coal consumption rate is based on the statistical data from China Electricity Council [33]. The price in this equation is in CNY, which is converted to U.S. dollars in other analyses. The calorific value of electricity coal is $5000 \mathrm{kcal} / \mathrm{kg}$, while the calorific value of standard coal is $7000 \mathrm{kcal} / \mathrm{kg}$. 10,000 is used for units conversion (from $\mathrm{CNY}$ to $\mathrm{CNY}$ cents, and from $\mathrm{g}$ to $\mathrm{t}$ ). 


\subsubsection{Cost and Income}

(1) Capital Cost

The capital cost of STCG includes direct capital cost and indirect capital cost.

$$
I_{\mathrm{CC}}=I_{\mathrm{DCC}}+I_{\mathrm{ICC}}
$$

where, $I_{\mathrm{CC}}, I_{\mathrm{DCC}}$, and $I_{\mathrm{ICC}}$ are referring to the capital cost, direct capital cost, and indirect capital cost of STCG respectively.

For STCG, the direct capital cost $I_{\mathrm{DCC}}$ includes investment cost of coal-fired power generation system (such as boiler, turbines, generator, etc.), solar tower field (such as heliostats, receiver, tower, thermal energy storage tanks, etc.), and the contingency of the plant project. While the indirect capital cost includes land cost, owner cost, sales tax, etc.

Due to lack of real solar tower aided coal-fired power plants, the capital cost $I_{\text {ICC }}$ of STCG comes from two parts: solar tower power plant and coal-fired power plant. What should be noted is that the cost of a power cycle in a solar tower power plant does not need to be accounted for when calculating the total capital cost of STCG, because the solar tower field shares its power cycle with the coal-fired power generation system.

Capital cost of both the solar tower power plant and coal-fired power plant have been taken from literature $[34,35]$.

(2) Operation and Maintenance Cost

The operation and maintenance $(\mathrm{O} \& \mathrm{M})$ cost consists of fixed cost and variable cost.

$$
I_{\mathrm{O} \& \mathrm{M}}=I_{\mathrm{O} \& \mathrm{M}, \mathrm{F}}+I_{\mathrm{O} \& \mathrm{M}, \mathrm{V}}
$$

where $I_{\mathrm{O} \& \mathrm{M}}$ is the total O\&M cost of STCG project, $I_{\mathrm{O} \& \mathrm{M}, \mathrm{F}}$ and $I_{\mathrm{O} \& \mathrm{M}, \mathrm{V}}$ are fixed and variable O\&M cost, respectively.

The variable O\&M cost in the $n$th year depends on the generating capacity and annual power output as indicated below,

$$
I_{\mathrm{O \& M}, \mathrm{V}}=\left(C_{\text {cap }} \cdot P_{\text {cap }}+C_{\text {gen }} \cdot P_{\text {gen }}\right)\left(1+r_{\text {inf }}\right)^{n-1}
$$

where, $C_{\text {cap }}$ is the O\&M cost per $\mathrm{kW}$ electricity in each year; $P_{\text {cap }}$ is the nameplate generating capacity; $C_{\text {gen }}$ is the O\&M cost per unit power generation,; $P_{\text {gen }}$ is the annual power output; $r_{\text {inf }}$ is the inflation rate, which can be found from reference [36]; and $n$ represents the $n$th year.

The O\&M cost can also be calculated by a simplified method [37]. The O\&M cost in the $n$th year is

$$
I_{\mathrm{O} \& \mathrm{M}}=I_{\mathrm{CC}} \cdot r_{\mathrm{O} \& \mathrm{M}}\left(1+r_{\mathrm{inf}}\right)^{n-1}
$$

where $r_{\mathrm{O} \& \mathrm{M}}$ is the proportion of O\&M cost to the capital cost of STCG project.

In order to guarantee the secure and stable high efficiency operation of the plant, annual overhaul and technological transformation are needed, whose costs are also included in the O\&M cost.

(3) Insurance Cost

The method for calculating insurance cost in the $n$th year is similar to that of O\&M cost [38],

$$
I_{\mathrm{ic}}=I_{\mathrm{CC}} \cdot r_{\mathrm{ins}} \cdot\left(1+r_{\mathrm{inf}}\right)^{n-1}
$$

where $r_{\text {ins }}$ is the insurance rate.

(4) Fuel Cost 
Coal is the only fuel used by a STCG plant, and the annual coal consumption depends on grid demand and annual DNI. The fuel cost in the $n$th year is

$$
I_{\mathrm{fc}}=m_{\text {coal }} \cdot p_{\text {coal }} \cdot\left(1+r_{\text {inf }}\right)^{n-1}
$$

where $m_{\text {coal }}$ is the total coal consumption in the $n$th year; $p_{\text {coal }}$ is the average coal price in the $n$th year.

(5) Interest of Debt

The interest of debt accounts for a large proportion of the debt repayment. The repayment is a dynamic process, so the interest paid to the bank in each year is different. The interest in the $n$th year is

$$
I_{\text {int }, n}=D_{n-1} \cdot r_{\text {int }}
$$

where $I_{\mathrm{int}, n}$ is the interest of debt in the $n$th year; $D_{n-1}$ is the remaining debt by the end of the $(n-1)$ th year; and $r_{\text {int }}$ is the interest rate of debt.

$I_{\text {int }, n}$ can be calculated by the remaining debt by the end of the $(n-2)$ th year and the repayment in the $(n-1)$ th year,

$$
D_{n-1}=D_{n-2}-P_{\text {pri, } n-1}
$$

where $P_{\text {pri,n-1 }}$ is the repayment to the bank on the principal cash in the $(n-1)$ th year and it can be calculated as:

$$
P_{\text {pri, } n-1}=P_{n-1}-I_{\text {int }, n-1}
$$

where, $P_{n-1}$ is the sum of principal cash and interest that needs to be paid to the bank in the $(n-1)$ th year.

The available money used to pay the bank depends on the annual income. The proportion of the available money to the annual income is called debt service coverage ratio (DSCR) [39]. DSCR should be no smaller than 1 , and the larger the DSCR is, the stronger the repayment capacity is.

$$
P_{\mathrm{ava}, n}=I_{\mathrm{inc}, n} / \mathrm{DSCR}
$$

where $P_{\text {ava }, n}$ is the available money used to pay the bank in the $n$th year, $I_{\text {inc, } n}$ is the annual income in the $n$th year.

Taking the discount rate into consideration, the income equivalence of the 0th year in the $n$th year is

$$
I_{\text {inc }, n, 0}=I_{\text {inc }, n} /\left(1+r_{\text {dis }}\right)^{n}
$$

where $r_{\text {dis }}$ is the discount rate.

If the available money in each year is converted to the 0th year by discount rate and then accumulated, the debt repayment capacity of the project can be obtained. The debt repayment capacity equals to the maximum debt the project owner(s) can borrow from the bank. If the debt is beyond the debt repayment capacity, that means the total income of the project cannot cover the debt from the bank.

In the repayment process, the available money each year is first used to pay for the interest, and then for the principal cash.

(6) Revenue of Electricity

Electricity revenue is the main income for a plant project, and it is related to the electricity market and government policies. Electricity price of different electricity sources (fossil fuels or renewable energy) differs along with different pricing mechanisms (see Section 2.2.1). 
The electricity revenue of a STCG plant comes from the electricity generated by solar thermal energy and coal.

$$
I_{\text {ele }}=\sum_{n=1}^{N}\left(P_{\text {sol }-n} \cdot p_{\text {sol }-n}+P_{\text {coal }-n} \cdot p_{\text {coal }-n}\right)
$$

where $I_{\text {ele }}$ is the total electricity revenue of a STCG plant for the whole life cycle; $N$ is the lifespan of a STCG plant; $P_{\text {sol }-n}$ is the power output of solar thermal energy in the $n$th year; $p_{\text {sol }-n}$ is the price of electricity generated by solar thermal energy in the $n$th year; $P_{\text {coal }-n}$ is the power output of coal in the $n$th year; $p_{\text {coal }-n}$ is the price of electricity generated by coal in the $n$th year. If electricity price changes monthly, the total revenue should also be calculated every month.

(7) Taxes

The main taxes imposed on a plant project include the value-added tax (VAT), the income tax, and the additional tax.

The VAT is a turnover tax based on the added value of goods during circulation. The taxable amount of a general taxpayer equals the difference between the current output tax and the current input tax

$$
T_{\mathrm{VAT}}=T_{\text {out-tax }}-T_{\text {in-tax }}
$$

where $T_{\mathrm{VAT}}$ is the value-added tax, $T_{\text {out-tax }}$ and $T_{\text {in-tax }}$ are the current output tax and the current input tax respectively.

The income tax is a tax imposed on taxpayers with their taxable income. The income tax rate for enterprises in China is $25 \%$.

The additional tax is a tax levied in accordance with a certain proportion of the regular tax, including urban maintenance and construction tax, educational surtax, etc. Based on current laws and regulations, the rates of urban maintenance and construction tax and educational surtax are $7 \%$ and $3 \%$ of the regular tax respectively.

\subsubsection{Assessment Indicators}

\section{- $\quad$ Static Indicators}

Static indicators refer to the indexes calculated directly with cash flows without considering the time value of money. They include static pay-back period, return on investment, etc.

\section{(1) Static Pay-Back Period (SPP)}

The static pay-back period is the time needed to recover the total investment without considering the time value of money, namely the time needed for accumulative net cash flows to just cover the total investment during project's life cycle. Generally, there are two forms of the static pay-back period: the operation period including or not the construction period. In this paper, the construction period is included into the static pay-back period (SPP), whose calculation method also fits the dynamic pay-back period. The static pay-back period and the dynamic pay-back period are generally calculated with the unit of year.

$$
\sum_{n=1}^{P P}\left(C I_{n}-C_{n}\right)=0
$$

where $P P$ is the static pay-back period, and $C I_{n}$ and $C O_{n}$ are cash inflow and cash outflow respectively.

The static pay-back period (SPP) can reflect the investment pay-back time with a simple calculation method. However, the time value and the cash flows after the static pay-back period are not considered, so it cannot accurately reflect the effect of different investment methods on the project.

(2) Return on Investment (ROI) 
The ROI refers to the ratio between the annual profit and the total investment of the project in normal productive years. If the annual profit changes drastically during the project's life cycle, the average annual pre-tax profit can be used instead of the annual profit in a particular year.

$$
\mathrm{ROI}=\mathrm{EBIT} / \mathrm{TI}
$$

where EBIT is the annual profit of the project and TI is the total investment of the project.

A project is worth investing when the ROI is no less than the benchmark yield of the project.

(3) Rate of Return on Common Stock Holders' Equity (ROE)

The ROE refers to the ratio between the annual after-tax net profit and the total capital of the project in normal productive years. If the annual after-tax net profit changes significantly during the project's life cycle, the average annual after-tax net profit can be used instead of the annual after-tax net profit.

$$
\mathrm{ROE}=\mathrm{NP} / \mathrm{EC}
$$

where NP is the annual after-tax net profit of the project and EC is the total capital of the project.

- Dynamic Indicators

Dynamic indicators refer to the indexes calculated with cash flows considering the time value of money. They include dynamic pay-back period, net present value, internal rate of return, LCOE, etc.

(1) Dynamic Pay-Back Period (DPP)

Compared with the static pay-back period presented above (SPP), the dynamic pay-back period (DPP) is the time needed to recover the total investment considering the time value of money, namely the time needed for accumulative net cash flows discounted by the benchmark yield to just cover the total investment during the project's life cycle. Units of the dynamic pay-back period (DPP) are the same ones as the static pay-back period (SPP).

$$
\sum_{n=1}^{P t} \frac{\left(C I_{n}-C O_{n}\right)}{(1+\mathrm{BY})^{n}}=0
$$

where $C I_{n}$ and $C O_{n}$ are cash inflow and cash outflow respectively, $P t$ is the dynamic pay-back period of the project, and BY is the benchmark yield.

The time value of money is considered in the analysis of the dynamic pay-back period, overcoming the disadvantages of the static pay-back period. Therefore, the dynamic pay-back period is longer than the static pay-back period. However, the calculation considering the time value of money is more complex, and the cash flows after dynamic pay-back period are ignored. Dynamic pay-back period will be meaningless if the net cash flows are negative after the dynamic pay-back period, and some other indicators are needed for financial evaluation of the project.

\section{(2) Net Present Value}

The NPV is the accumulation of annual net cash flows discounted by the benchmark yield to the beginning of the project. The time value of money and the temporal distribution of cash flows in the project life cycle are considered in calculating NPV, which can reflect the profits and losses of the project by money. The NPV can be calculated as [40]

$$
\mathrm{NPV}=\sum_{n=1}^{N} \frac{C_{n}}{(1+\mathrm{BY})^{n}}
$$

where $C_{n}$ is the annual net cash flows in the $n$th year. 
Annual net cash flows are the difference between the annual cash inflows and annual cash outflows

$$
C_{n}=C I_{n}-\mathrm{CO}_{n}
$$

The NPV is a dynamic indicator that can reflect the profitability of the technical solution in the project life cycle. If the NPV is higher than 0, extra revenue can be obtained besides the profits that can meet the profitability requirement of the benchmark yield; if the NPV is equal to 0 , the project can meet the profitability requirement of the benchmark yield and is financially feasible; if the NPV is lower than 0 , the profit cannot meet the profitability requirement of the benchmark yield, and the project is not financially feasible.

(3) Internal Rate of Return (IRR)

The IRR is the discount rate when the total cash inflows and outflows at present are equal to each other (i.e., NPV $=0$ ), which is the rate of return desired by investors. The IRR is also known as investors' tolerance of inflation.

The IRR can be calculated as

$$
\mathrm{NPV}=\sum_{n=1}^{N} \frac{C_{n}}{(1+\mathrm{IRR})^{n}}=0
$$

When the IRR is equal to the average inflation rate during the project's life cycle, the project will not generate profits but is still feasible; if the IRR is lower than the average inflation rate, the project may probably suffer losses; if the IRR is higher than the average inflation rate, the project may probably earn profits. This is the most practical and important significance of the IRR for a project, especially for projects with a long pay-back period.

(4) Levelized Cost of Electricity

The LCOE is an assessment criterion used to evaluate the cost of power generation technologies. It is related to capital cost, O\&M cost, insurance cost, power output, and debt, etc. The LCOE is defined as the ratio between the overall cost and the total power output of project in its life cycle [41-44], namely

$$
\mathrm{LCOE}=\left(\sum_{n=0}^{N} \frac{\text { Cost }_{n}}{\left(1+r_{\mathrm{dis}}\right)^{n}}\right) /\left(\sum_{n=0}^{N} \frac{P_{\text {gen }, n}}{\left(1+r_{\mathrm{dis}}\right)^{n}}\right)
$$

where $\operatorname{Cost}_{n}$ is the annual cost in the $n$th year, and $P_{\text {gen, } n}$ is the annual power output in the $n$th year.

In the numerator of the equation above, the annual cost in each year is discounted. For the 0th year, the annual cost means the capital cost, which does not need to be discounted. Therefore, the equation above can be expressed as

$$
\mathrm{LCOE}=\left(I_{c c}+\sum_{n=1}^{N} \frac{\operatorname{Cost}_{\mathrm{ann}, n}}{\left(1+r_{\mathrm{dis}}\right)^{n}}\right) /\left(\sum_{n=1}^{N} \frac{P_{\text {gen }, n}}{\left(1+r_{\mathrm{dis}}\right)^{n}}\right)
$$

where $\operatorname{Cost}_{\mathrm{ann}, n}$ is the annual cost in the $n$th year (from the first year), including the O\&M cost, the fuel cost, the insurance cost, etc.

Considering the investment, the power output and the time value of money, the LCOE can reflect the generating cost of the project. Therefore, the LCOE is an important criterion to assess the generating cost of a plant project.

\section{System Description}

A STCG consists of three parts: solar tower field, coal-fired power generation system, and salt-water/steam heat exchangers. Diagram of STCG plant can be found in Figure 1. 
In Figure 1, the sunshine is reflected and focused on the central receiver atop the tower. Having absorbed heat into the receiver, the high-temperature heat transfer fluid (molten salt) flows into the hot tank. The flow rate of the molten salt out of the hot tank is adjusted according to the operation strategy of STCG. The high-temperature molten salt releases heat to reheat steam and feedwater by means of two heat exchangers before flowing into the cold tank. Cold molten salt in the cold tank is pumped back to the central receiver for the next cycle according to needs.

Reheated steam heated by the high-temperature solar thermal energy can further absorb energy in the reheater set in the boiler before reaching the target temperature. While feedwater is heated by using low-temperature solar thermal energy and later pumped into the boiler in order to absorb heat until reaching the target temperature.

Due to the fact that solar thermal energy plays an auxiliary role in the coupled system, the coal-fired power generation system should operate as stably as possible under optimized design conditions. Power plant should run based on grid demand, and the operation strategy should be adjusted according to the DNI. Under design point conditions, the solar tower field can provide enough thermal energy to generate 100 MWe under different solar multiples with different heliostat fields or thermal energy storages. When thermal energy from solar tower field and storage tank is sufficient to generate $100 \mathrm{MWe}$, the solar tower field will supply the thermal energy to the coal-fired power generation system, and the flow rate of the molten salt out of the hot tank will remain unchanged. If solar thermal energy is not sufficient to generate $100 \mathrm{MWe}$, the salt-water/steam heat exchangers will be cut off, so as to make the coal-fired power generation system run under its own operation conditions, with the solar tower field being in the state of heat accumulation and preservation.

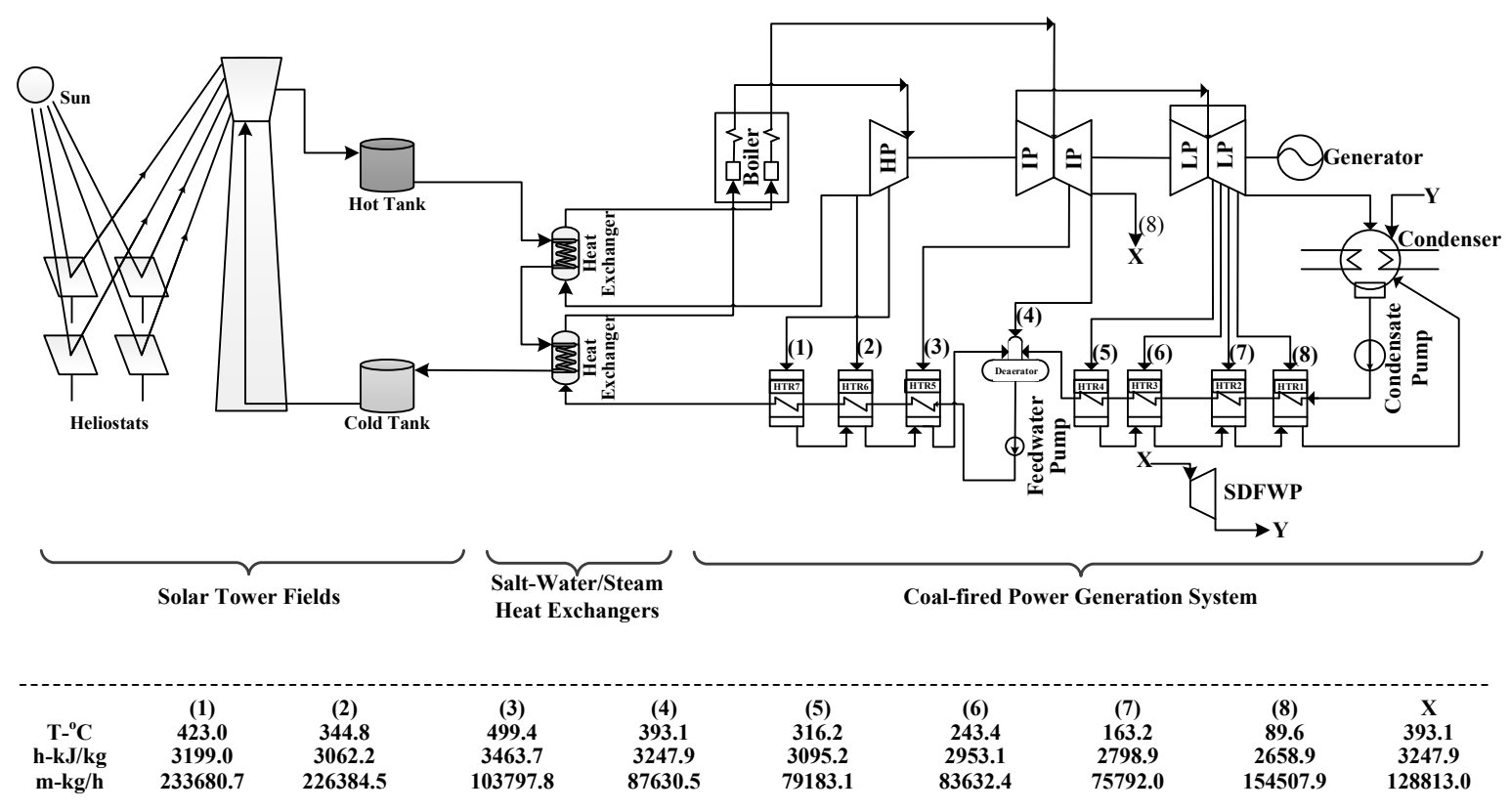

Figure 1. Diagram of STCG.

Due to the fact that solar thermal energy plays a secondary role in the coupled system, solar thermal energy provided by the solar tower field will never exceed the demand of the reheat steam even under off-design conditions. Therefore, molten salt flow rate in the salt-water/steam heat exchangers does not need frequent adjustments under off-design operation conditions, and the solar tower field can run according to its own operation strategy. 


\section{Case Study}

Financial models presented in Section 2 are used to analyze the economic characteristics of STCG in its life cycle. The electricity generated by coal and solar is distinguished by the method mentioned in Section 2.1. The electricity prices for solar and coal are calculated according to the model in Section 2.2.1. The investments of project are analyzed according to models in Section 2.2.2, and sensitivity analysis can be made according to the indicators in Section 2.2.3.

\subsection{Project Investment}

Project investment mainly includes the investment in construction and operation. Construction investment consists of fixed assets investment, interest during construction, working capital, etc. The operation investment consists of fuel cost, O\&M cost, insurance cost, payroll and benefits, interest during operation, and taxes.

\subsubsection{Construction Investment}

For STCG plant project, the construction capital cost consists of the investment in solar tower field and coal-fired power generation system. The investments in turbines, regenerative system, condenser, and generator for the solar tower power plant are not considered, since solar tower thermal energy generates electricity by sharing the turbines, condenser, and generator with the coal-fired power plant, which can reduce the investment in solar tower system. The capital cost break-down of a solar tower aided coal-fired power plant project are shown in Figure 2 [34,35].

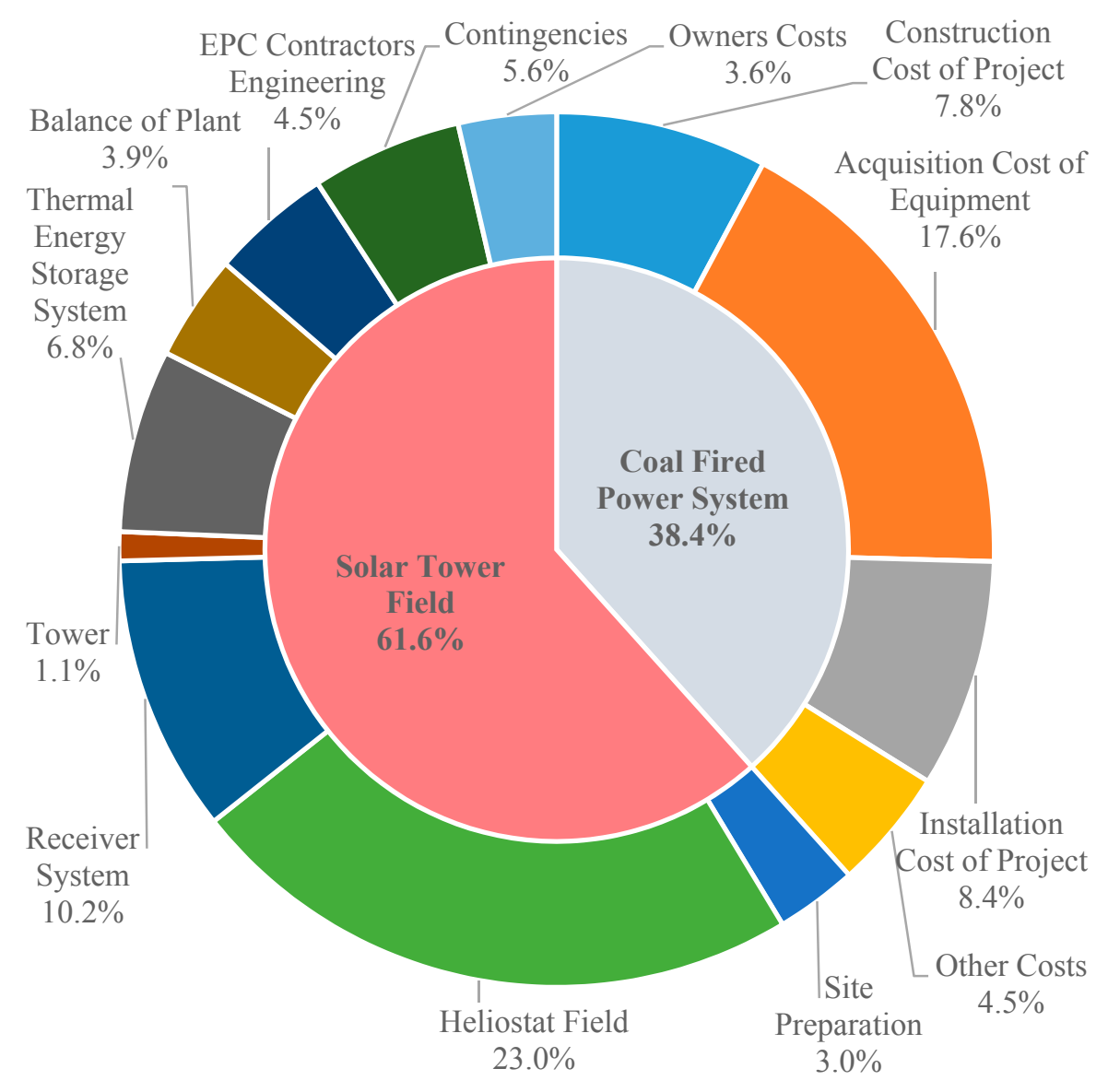

Figure 2. Capital cost break-down of the solar tower aided coal-fired power plant project. 
As shown in Figure 2, the capital cost of the solar tower field is the main part (about 61.6\%) of that of a STCG plant project. Seen from the power output of the solar tower field and the coal-fired power generation system, the investment in the solar tower field is over 10 times more than that of the coal-fired power generation system.

The capital cost of a 100 MWe solar tower power plant (with $15 \mathrm{~h}$ of thermal energy storage) is United States Dollar (USD) 900 million. The capital cost of power cycle accounts for about $11.3 \%$ of that of the solar tower power plant, with the rest included in the capital cost of the STCG plant project. Most of the capital cost of a solar tower field is due to the heliostat field and the receiver, which is larger than half of that of the solar tower power plant (Figure 2). The estimated investment of $100 \mathrm{MWe}$ solar tower field is shown in Table 1.

Table 1. Estimated investment of 100 MWe solar tower field.

\begin{tabular}{clcc}
\hline Parameters & Units & Value & Proportion (\%) \\
\hline EPC Contractors Costs & Million USD & 751.8 & 94.12 \\
Site Preparation & Million USD & 39.0 & 4.89 \\
Heliostat Field & Million USD & 297.6 & 37.26 \\
Receiver System & Million USD & 132.8 & 16.63 \\
Tower & Million USD & 13.8 & 1.73 \\
Thermal Energy Storage System & Million USD & 87.7 & 10.98 \\
Balance of Plant & Million USD & 50.6 & 6.34 \\
EPC Contractors Engineering & Million USD & 57.8 & 7.24 \\
Contingencies & Million USD & 72.3 & 9.05 \\
Owners Costs & Million USD & 47.0 & 5.88 \\
In Total & Million USD & 798.7 & 100 \\
\hline
\end{tabular}

It can be seen from Table 1 that the capital cost of heliostat field, receiver, and thermal energy storage accounts for about $65 \%$ of that of the solar tower power plant. Therefore, the three components play a key role in reducing the capital cost of the solar tower power plant.

The investment of the coal-fired power generation system in STCG is the same to that of a coal-fired power plant. The total capital cost of 1000 MWe coal-fired power plant is USD 496.9 million, and the estimated investment is shown in Table 2 [35].

Table 2. Estimated investment of 1000 MWe coal-fired power generation system.

\begin{tabular}{cccc}
\hline Parameters & Units & Value & Proportion (\%) \\
\hline Construction Cost of Project & Million USD & 101.3 & 20.39 \\
Acquisition Cost of Equipment & Million USD & 228.2 & 45.92 \\
Installation Cost of Project & Million USD & 109.5 & 22.04 \\
Other Costs & Million USD & 57.9 & 11.65 \\
\hline
\end{tabular}

In Table 2, the investment of the coal-fired power plant consists of four main parts: the construction cost $(20.4 \%)$, the acquisition cost of equipment $(45.9 \%)$, the installation cost $(22.0 \%)$, and other costs $(11.7 \%)$. Due to the fact that coal-fired power plant investment is out of the scope of this paper, and it will not affect the study, it is not going to be analyzed in detail.

Working capital is set to buy coal and equipment and to pay the employees by the end of the construction period. In this paper, the working capital is set to be $2 \%$ of the capital cost of a STCG plant project.

\subsubsection{Operation Investment}

The operation investment consists of fuel costs, O\&M costs, insurance costs, payroll and benefits, interest during operation and taxes, etc. 
Daily O\&M cost (including mirror cleaning, component replacement and maintenance, etc.) is necessary when running a STCG plant. Due to the lack of real STCG plants, the annual O\&M cost (Equation (5)) has been set to be $2 \%$ of the capital cost of the STCG plant project [37].

Insurance purchasing for solar tower power plant is particularly important, so the annual insurance (Equation (6)) is set to be $0.5 \%$ of the capital cost of the STCG plant project [38].

The coal price changes in real time under the effect of the coal market. In this paper, the $5000 \mathrm{kcal}$ coal is adopted to calculate the electricity price (Equation (1)) with the price index of electricity coal and the standard coal consumption rate [33]. Due to a lack of a price index of electricity coal for the past 25 years, the monthly price index of 2014 has been taken as the annual price index for calculation.

Considering that this size of plant employs 200 workers with an average salary (including welfare) of USD 12,500/person-year.

Cost depreciation is based on the fixed assets. In this paper, the residual rate of fixed assets is seen as 0 , and the depreciation period is 25 years.

Plant owner shall pay sales taxes and additional taxes (Equation (14)) for the revenue of electricity, and pay income taxes according to the profits of the project. According to the national standards, the corporate income tax rate is $25 \%$ and the value-added tax rate is $17 \%$. Additional taxes include the urban maintenance and construction tax and the educational surtax, with the tax rates being $7 \%$ and $3 \%$ of the VAT, respectively.

According to the agreement between the project owner and the bank, the debt should be paid within the repayment period. The interest rate for long-term (longer than five years) debt is $4.9 \%$ [45]. The yearly revenue is first used to pay for the interest in the current year and the rest is used to pay for the principal of debt. The remaining debt is included in the next year's payment. The repayment period in this paper is assumed to be 15 years.

\subsection{Electricity Generation}

The assumed STCG is located in Delingha, China, and the main designing parameters of this plant are shown in Table 3.

Table 3. Main designing parameters of STCG plant.

\begin{tabular}{llc}
\hline Systems & Parameters & Value \\
\hline \multirow{5}{*}{ Solar Tower Field } & Annual DNI $\left(\mathrm{W} / \mathrm{m}^{2}\right)$ & 2385.1 \\
& Heliostat area $\left(\mathrm{m}^{2}\right)$ & $1.50 \times 10^{6}$ \\
& Mass flow rate of molten salt for heating water $/ \mathrm{steam}(\mathrm{kg} / \mathrm{s})$ & 580.7 \\
& Solar Multiple & 2.5 \\
& Inlet temperature $\left({ }^{\circ} \mathrm{C}\right)$ & 301.8 \\
& Outlet temperature $\left({ }^{\circ} \mathrm{C}\right)$ & 565 \\
& Thermal energy transferred to coal-fired power system $\left(\mathrm{MW}_{\mathrm{th}}\right)$ & 243.1 \\
\hline & Generating capacity $(\mathrm{MW})$ & 1008.3 \\
& Parameters of main steam $\left(\mathrm{MPa} /{ }^{\circ} \mathrm{C} / \mathrm{t} / \mathrm{h}\right)$ & $25.0 / 600 / 2733.4$ \\
Coal-Fired Power System & Parameters of reheated steam $\left(\mathrm{MPa} /{ }^{\circ} \mathrm{C} / \mathrm{t} / \mathrm{h}\right)$ & $4.25 / 600 / 2273.4$ \\
& Press of condenser $(\mathrm{kPa})$ & 5.6 \\
& Coal consumption rate $(\mathrm{g} / \mathrm{kWh})$ & 236.4 \\
\hline
\end{tabular}

A STCG plant generates electricity according to grid demand. The ratio between solar thermal energy and coal changes in real time according to the DNI and power demand. The hourly parameters-including grid demand, power output, coal consumption, DNI, and others-are needed for the techno-economic analysis of a STCG plant project in its life cycle.

The grid always dispatches electricity from coal-fired power plants according to the electrical load in its supply area. Coal-fired power plants always run under off-design conditions because of the large variation range of electricity dispatch. Annual electricity grid demand for 1000 MWe coal-fired power plant can be found in Figure 3, which results into an annual power output of $7330.8 \mathrm{GWh}$. According to statistical data from China Electricity Council [33], annual average utilization time of the countrywide 
power generation assemblies is $4318 \mathrm{~h}$. Considering the advantages of high efficiency, low emissions, and its ability for peak-load shaving, annual average utilization time of the coal-fired power plant studied in this paper is set to be $5500 \mathrm{~h}$, which is consistent with China's current power market.

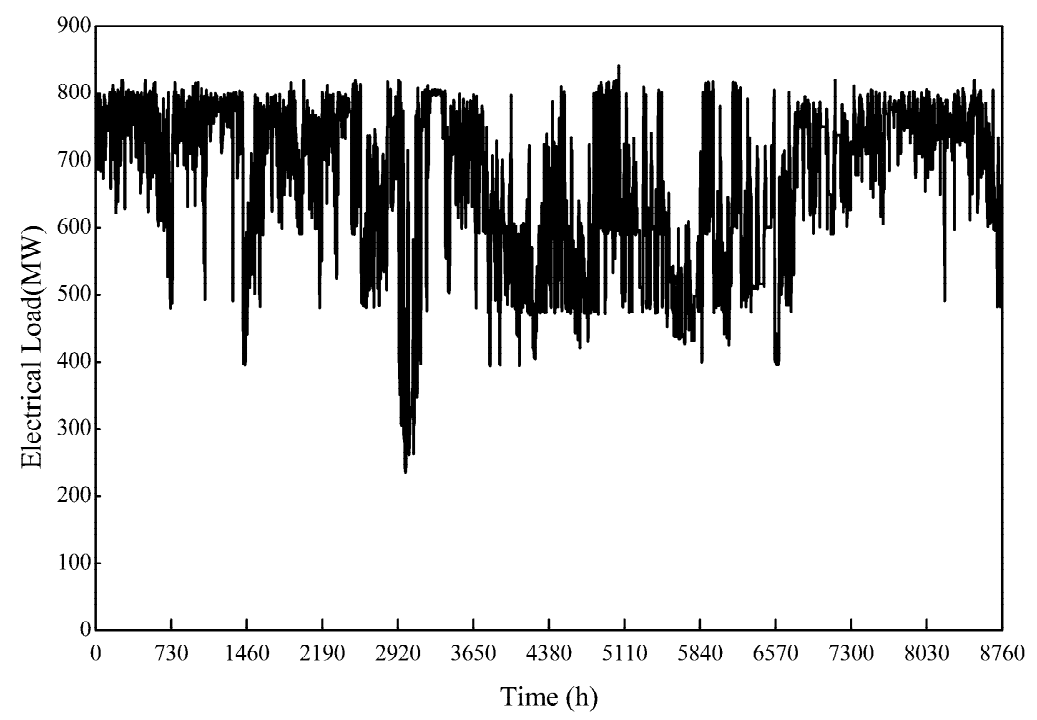

Figure 3. Annual hourly power dispatching of a coal-fired power plant from the grid company.

The STCG plant in this paper is assumed to be located in Delingha, Gansu Province, China. DNI data for this location are taken from National Renewable Energy Laboratory (NREL) [46].

Due to the fact that there is only 1 year's data for grid power dispatching but 15 years' data for the DNI while power plant life cycle is set to 25 years, some data must be reused for life cycle analysis. Annual DNI data along the 15 years database significantly changed, then it was decided to consider only DNI data for the 10 years providing closer DNI to the annual average value.

Power plant models are built and verified using Ebsilon Professional [47,48]. Solar contribution methods described in previous works is used to calculate the hourly power output generated by solar thermal energy and coal [31].

Annual power output, annual coal consumption, and annual DNI of the STCG plant project are shown in Figure 4.

It can be seen from Figure 4 that the power output in each year is almost the same to each other with the same power dispatching of grid. What changes year over year is the annual power output produced using solar thermal energy due to the different annual DNI. Variation trend found for the annual power output produced by solar thermal energy is the same to that of the annual DNI. Therefore, the variation trend of annual coal consumption is opposite to that of the annual DNI. Over 25 years, a STCG plant can generate 142,822 GWh electricity, 148,021 GWh and 128,021 GWh of which are generated by solar thermal energy and coal respectively. Solar thermal energy takes up from $21.3 \%$ to $24.5 \%$ of the total energy input (solar thermal energy and coal energy). While the power output from solar thermal energy takes up from $9.8 \%$ to $11.4 \%$ of the total power output. Average generating efficiency of a STCG plant for its whole life cycle is around 37.5\% while average solar-to-electricity efficiency is around $17.3 \%$, which is higher than that of solar tower thermal power plants (that are ranging from $7.7 \%$ to $14.8 \%$ ) [49], and average coal-to-electricity efficiency is around $43.3 \%$.

Annual power output from solar thermal energy and coal depends on the annual DNI of every year. By the end of the year, these differences are not that obvious as it was observed in Figure 4. However, monthly power output in a year changes greatly, as it can be observed in Figure 5 for the 15 th year. 


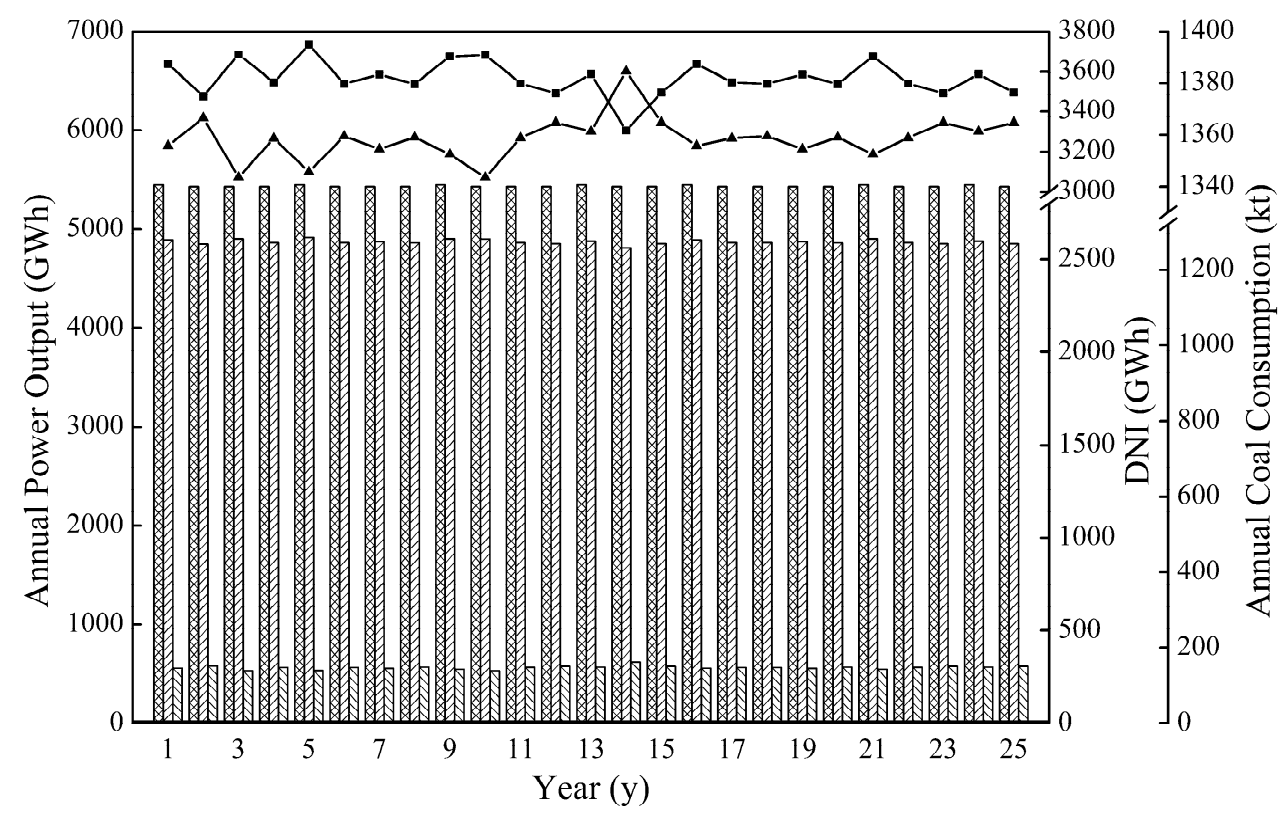

Annual Power Output $1 \mathrm{~T}$ Annual Power Output by Coal Annual Power Output by Solar $\longrightarrow$ DNI $\longrightarrow$ Annual Coal Consumption

Figure 4. Annual power output and coal consumption of the STCG.

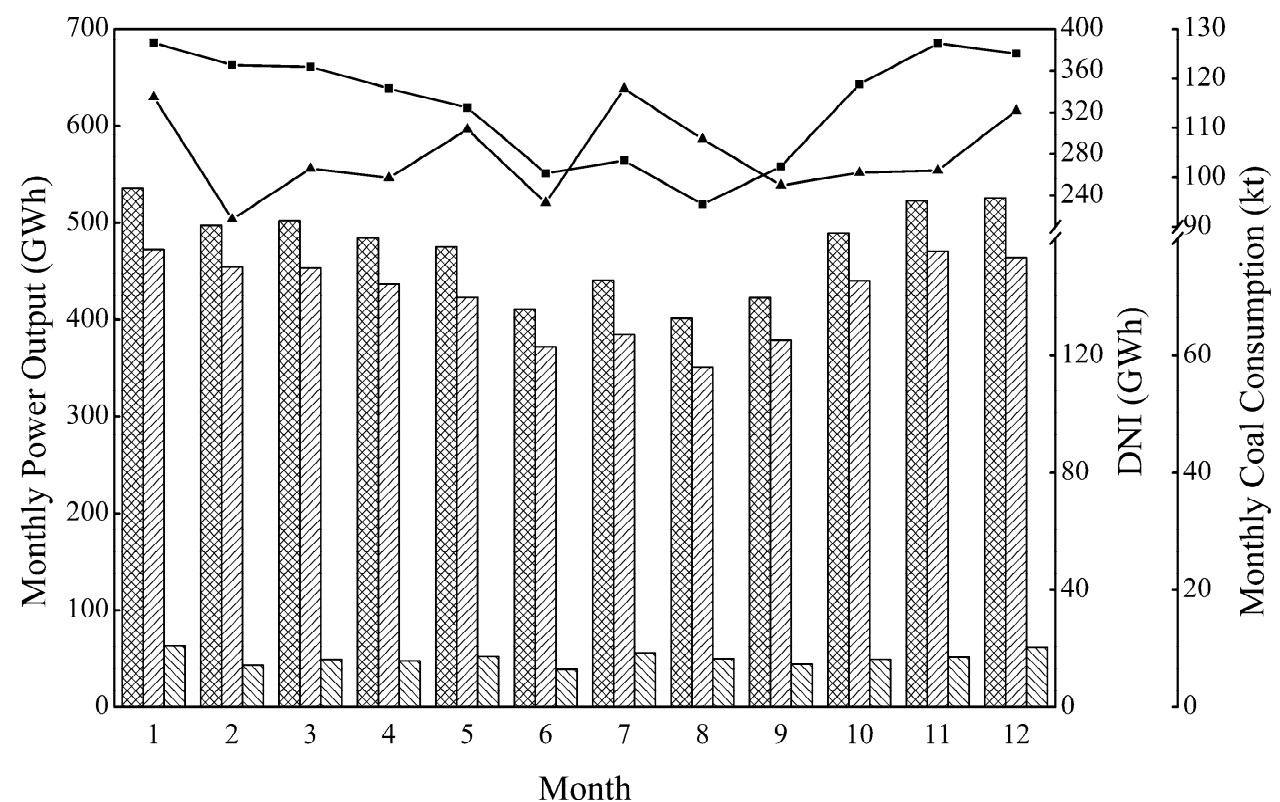

Monthly Power Output 1 Monthly Power Output y Coal $M$ Monthly Power Output by Solar
- DNI

Figure 5. Monthly power output and coal consumption of STCG.

Figure 5 shows that monthly DNI for January, May, July, and December are higher among the other months. As it can be observed, Delingha DNI differs from that of some other places [50]. Monthly power output from solar thermal energy depends on monthly DNI and has the same variation trend. Power dispatching from January to March and from October to December is a little higher than that from April to September. The monthly coal consumption and the monthly DNI are implicitly related, because the total power output from the plant and the monthly DNI change every month. However, 
the monthly coal consumption has the same variation trend to that of the monthly power output, because the power output from coal accounts for more than $87 \%$ of the total power output.

Total coal consumption of the STCG plant is $34,547,047.5 \mathrm{t}$, lower than that of a coal-fired power plant with same power dispatching for its whole life cycle, which is translated into a $\mathrm{CO}_{2}$ emissions reduction of about $13,125,410 \mathrm{t}\left(107.7 \mathrm{~g} / \mathrm{kWh}\right.$ in a whole life cycle). When calculating $\mathrm{CO}_{2}$ emission, a kind of real coal is used [29].

\subsection{PPA Price}

Due to the lack of real STCG plants, electricity prices for this kind of technology cannot be found. In this paper, existing electricity prices (for solar thermal power plants and coal-fired power plants) are taken in order to analyze the revenue of electricity of a STCG plant project.

For the electricity generated by solar thermal energy, the PPA price is 18.75 cents $/ \mathrm{kWh}$ [51] while coal electricity price linkage policy (Equation (1)) is used to estimate the price of electricity generated by coal [52].

Due to the lack of electricity coal price index for the past 25 years, 2014 monthly price index has been taken as the annual price index to calculate the electricity price. Therefore, there is a small change on the electricity price, and the average electricity price for coal electricity is 5.558 cents $/ \mathrm{kWh}$.

\subsection{Financial Analysis}

A financial analysis is to study the financial issues about investment and revenue of a plant project, including capital cost, income, pay-back period, profit rate, etc.

Figure 6 shows the accumulative after-tax net-cash-flow in the life cycle of the 1000 MWe STCG plant project. The project is under investment state during the construction period, and the liability increases with a negative accumulative NPV. During the operation period, the liability decreases because of the revenue of electricity sales. All the cost can be recovered by 12 years and 3 months (including the construction period), which is the static pay-back period. After that, the project will be in a profitable state with gains of USD 2.35 billion by the end of the operation period.

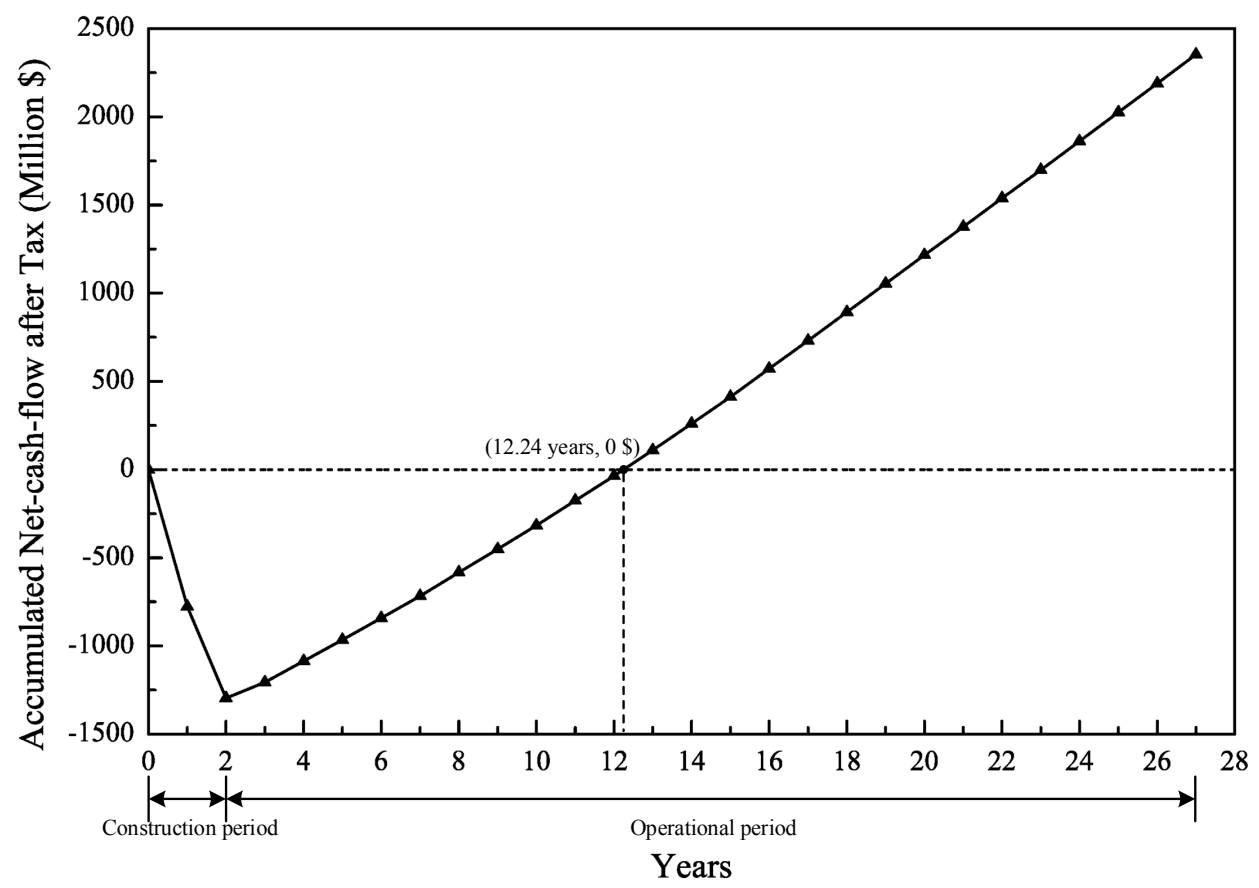

Figure 6. Accumulative after-tax net-cash-flow in the life cycle of 1000 MWe STCG. 
Profitability is one of the most noteworthy indexes for an enterprise. The total cost of a STCG plant project is USD 5.03 billion, the total revenue of electricity sales is USD 9.41 billion, and the total profit is USD 3.06 billion.

The financial summary of 1000 MWe STCG plant project is shown in Table 4.

Table 4. Financial summary of 1000 MWe STCG.

\begin{tabular}{|c|c|c|c|}
\hline Parameters & Units & Value & Remarks \\
\hline Total Electricity Selling Income & Million USD & 9413.1 & \\
\hline Electricity Selling Income from Solar Energy & Million USD & 2641.3 & \\
\hline Electricity Selling Income from Coal & Million USD & 6771.8 & \\
\hline Total Costs & Million USD & 5028.9 & \\
\hline Investment during Construction Period & Million USD & 1378.1 & \multirow{4}{*}{ 2-year construction period } \\
\hline Capital Cost & Million USD & 1295.6 & \\
\hline Interest during Construction Period & Million USD & 56.6 & \\
\hline Working Capital & Million USD & 25.9 & \\
\hline Investment during Operation Period & Million USD & 3650.7 & \multirow{6}{*}{$\begin{array}{l}25 \text {-year operation period, } 15 \text {-year } \\
\text { repayment period }\end{array}$} \\
\hline O\&M Costs & Million USD & 647.8 & \\
\hline Insurance Costs & Million USD & 162.0 & \\
\hline Fuel Costs (Equation (7)) & Million USD & 2340.5 & \\
\hline Payroll \& Benefit & Million USD & 62.5 & \\
\hline Interest during Operation Period (Equation (8)) & Million USD & 438.0 & \\
\hline Sales Tax and Additional Taxes & Million USD & 1322.6 & \multirow{13}{*}{$\begin{array}{l}\text { After tax } \\
\text { After tax } \\
\text { Including construction period, after tax } \\
\text { Including construction period, after tax } \\
\text { Before operation } \\
\text { In the last year of the operation period }\end{array}$} \\
\hline Total Profit & Million USD & 3061.6 & \\
\hline ROI (Equation (16)) & $\%$ & 8.89 & \\
\hline Profit and Tax Investment Ratio & $\%$ & 12.72 & \\
\hline ROE (Equation (17)) & $\%$ & 35.45 & \\
\hline IRR (Equation (21)) & $\%$ & 8.68 & \\
\hline NPV (Equation (19)) & Million USD & 80.74 & \\
\hline SPP (Equation (15)) & years & 12.24 & \\
\hline DPP (Equation (18)) & years & 23.45 & \\
\hline & $\%$ & 81.20 & \\
\hline Debt to Assets Ratio & $\%$ & 2.06 & \\
\hline Investment per $\mathrm{kW}$ & $\mathrm{USD} / \mathrm{kW}$ & 1432 & \\
\hline LCOE (Equations (22) and (23)) & $\mathrm{USD} / \mathrm{kWh}$ & 0.062 & \\
\hline
\end{tabular}

Table 4 shows that the total revenue of selling electricity (by the end of the operation period) is USD 9.41 billion, which is 1.87 times the total cost (5.03 billion dollars). Deducting selling taxes and additional taxes (USD 1.32 billion), the total profit of the project is USD 3.06 billion, which is $32.5 \%$ of the total revenue of selling electricity.

The static pay-back period (SPP) of the plant project is 12.24 years, and all the cost can be recovered in 11 years (excluding the construction period). The return of the investment of the project is $8.89 \%$, and the profit and tax investment ratio is $12.72 \%$. The debt-to-assets ratio of the project reduces from $81.20 \%$ (at the beginning of operation period) to $2.06 \%$ (in the last year of the repayment period), indicating strong repaying ability and low financial risk of the project.

If the benchmark yield is assumed to be $8 \%$, the dynamic pay-back period (DPP) of the project will be 23.45 years (including the construction period). The IRR after tax of the project is $8.68 \%$, and the NPV after tax is USD 80.74 million. The IRR of the project is higher than the assumed benchmark yield with high NPV, indicating that the project is worth investing.

After calculation, the investment of this project is $1432 \mathrm{USD} / \mathrm{kW}$, and the LCOE is $0.062 \mathrm{USD} / \mathrm{kWh}$, lower than that $(0.19 \mathrm{USD} / \mathrm{kWh})$ reported from installed solar tower thermal power plants [49], and higher than that $(0.037 \mathrm{USD} / \mathrm{kWh})$ of coal-fired power plant at the same place and under the same power dispatch with STCG in this paper.

In [48], the solar to electricity efficiency of the solar tower power generation system (Solar tower power generation system (STG) that has the same heliostat field with the solar tower field in this paper) is $17.66 \%$, and the power generation efficiency of coal-fired power generation system (CPG, that has the same generation capacity with STCG in this paper) is $45.52 \%$. The power generation efficiency of STCG in this paper is $40.43 \%$, which is between the above two efficiencies. Besides, the average power generation efficiency of STG and CPG is 39.93\%, lower than the power generation efficiency of STCG. 
Hence, STCG can generate electricity more efficiently than the average power generation efficiency of STG with the same heliostat field and CPG of the same size.

As for the economic issue, the LCOEs of STG, CPG, and STCG are 0.19, 0.037, and $0.062 \mathrm{USD} / \mathrm{kWh}$ respectively. In addition, the LCOE of STCG is lower than the average LCOEs of STG and CPG, because the total investments of STG and CPG are higher than that of STCG when they can generate the same amount of electricity. Therefore, STCG is not simply putting solar tower power plant and coal-fired power plant together, but being more efficient and cost-efficient in electricity generation.

\subsection{Sensitivity Analysis}

The static and dynamic indicators of a STCG plant project are affected by many factors, including area of the solar tower field, capital cost of the solar tower field, capital cost of the coal-fired power generation system, coal price, electricity price for solar thermal energy and coal, interest rate of debt, etc.

The solar tower field studied in the STCG can provide enough heat to generate $100 \mathrm{MWe}$, and the solar multiple is also based on this capacity. For different solar multiples (SM), the area of heliostat field and thermal energy storage capacity will change greatly. The investment of solar tower field accounts for over half of the total investment in the STCG plant project as it was discussed in Section 4.1. Therefore, SM can impose great effect on the investment in a STCG plant project. Figure 7 shows the effect of considering different solar multiples (SM) on LCOE, IRR, and NPV.

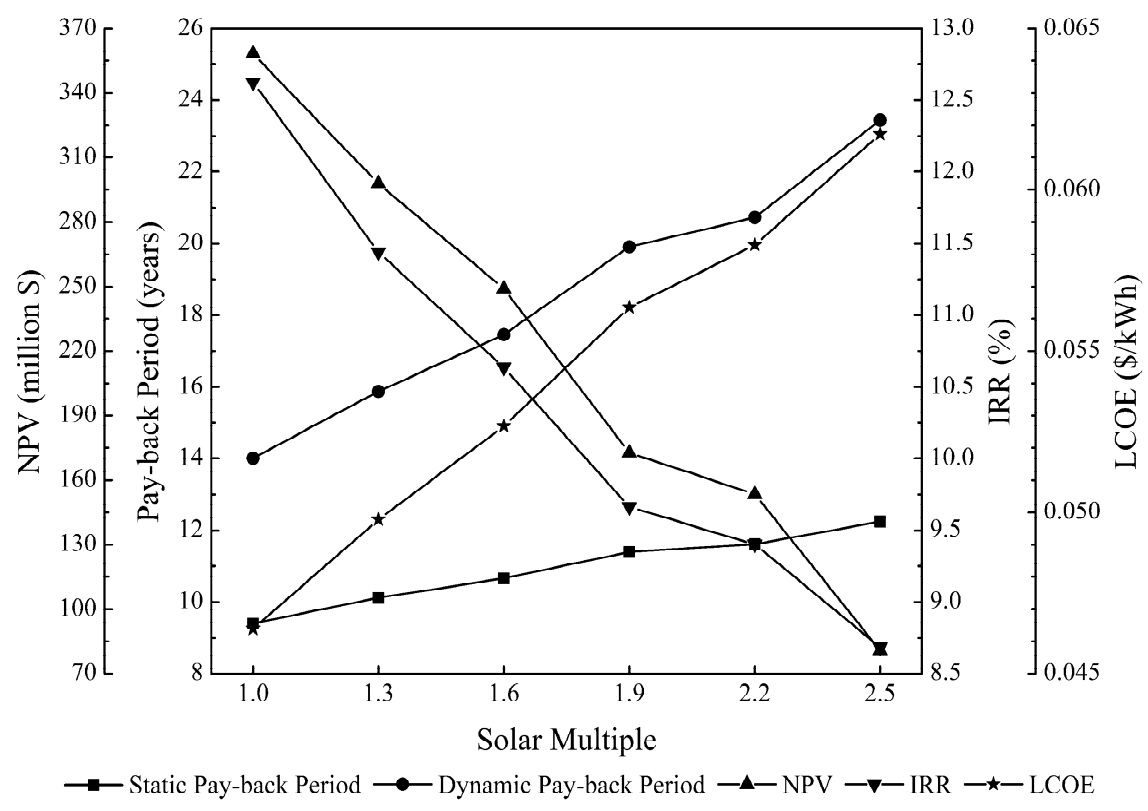

Figure 7. Effect on LCOE, IRR, and NPV of STCG by solar multiple.

Figure 7 shows that the static pay-back period (SPP) of a STCG plant project increases from 9.4 years to 12.2 years, and the dynamic pay-back period (DPP) increases from 14.0 years to 23.5 years along with the increase of SM from 1.0 to 2.5. With the increase of SM, the NPV decreases from USD 358.15 million to 80.74 million (by $77.5 \%$ ), the IRR decreases from $12.6 \%$ to $8.7 \%$ (by $31.2 \%$ ), and the LCOE increases from $0.0464 \mathrm{USD} / \mathrm{kWh}$ to $0.0617 \mathrm{USD} / \mathrm{kWh}$ (by $33.0 \%$ ). The main reason for these changes is the changes of the capital cost of the solar tower field. Increasing SM from 1.0 to 2.5, the size of the heliostat field, central receiver, and thermal energy storage system will increase significantly. With the increase of the capital cost of the solar tower field, the proportion of the capital cost of the solar tower field to the total capital cost of a STCG plant increases from $37.8 \%$ to $61.6 \%$. 
Coal-fired power generation is a proven technology with stable investment. Due to coal electricity price linkage policy discussed on Section 2.2.1, coal-generated electricity price changes along with the change of coal price. Therefore, in the sensitivity analysis, some factors (i.e., the capital cost of the coal-fired power plant, the price of the coal-generated electricity) are not analyzed.

Figure 8 shows the effect of different factors (i.e., cost of solar tower field, coal price, PPA of solar electricity and interest rate) on the static pay-back period (SPP) and dynamic pay-back period (DPP) for the STCG plant.

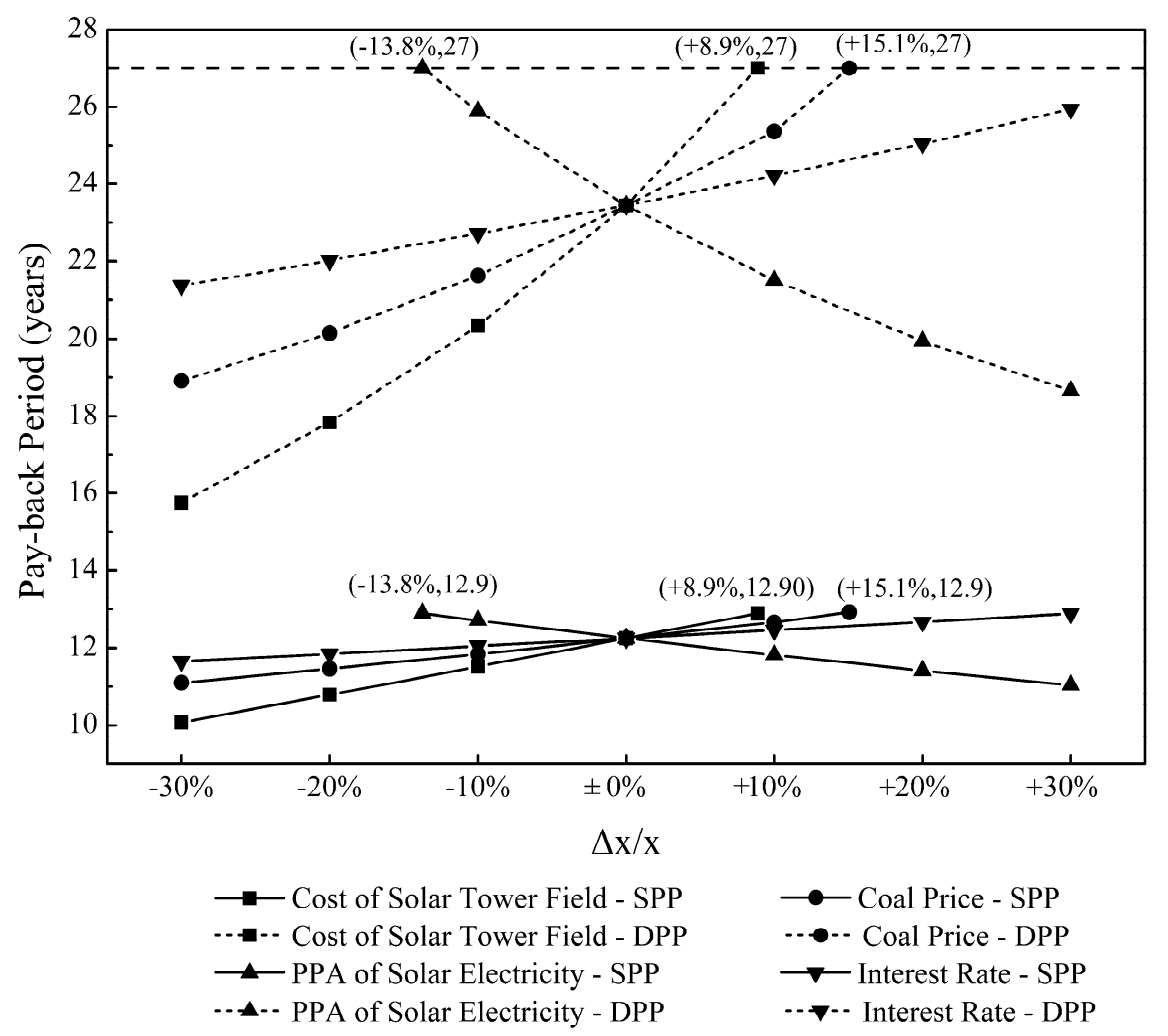

Figure 8. Effect on SPP and DPP of STCG by different factors.

In Figure 8, solid lines represent changes on static pay-back period (SPP) while dashed ones refer to dynamic pay-back period (DPP), as it can be observed, time period for DPP is longer than SPP. It can also be observed that parameters modification $( \pm 10, \pm 20$, and $\pm 30 \%)$ produces the variation trends on SPP and DPP. Total cost of a STCG plant project will increase along with the increase of the capital cost of the solar tower field or coal price or interest rate, which can also extend the pay-back period. In contrast, the increase of PPA of solar electricity can reduce the pay-back period. If the capital cost of the solar tower field increases by $8.9 \%$, or the coal price increases by $15.1 \%$ or PPA of solar electricity decreases by $13.8 \%$, the DPP will be 27 years (the sum of construction period and operation period), which means all cost cannot be recovered by the end of the project life. It should be noted that, when analyzing the effect of one factor on the pay-back period, the other factors are kept unchanged $( \pm 0 \%)$, and the same applies for the next analysis.

Figure 9 shows the effect of different factors on NPV for the STCG plant. In Figure 9, the net present value (NPV) goes down as the capital cost of the solar tower field, coal price, or interest rate of debt increases; while NPV increases as power purchase agreement (PPA) of solar electricity increases. When the capital cost of the solar tower field increases by $8.9 \%$ (or coal price increases by $15.1 \%$ or PPA price decreases by $13.8 \%$ ), the NPV of the project will be 0 , which means the project will break even at the end of the operation period. 


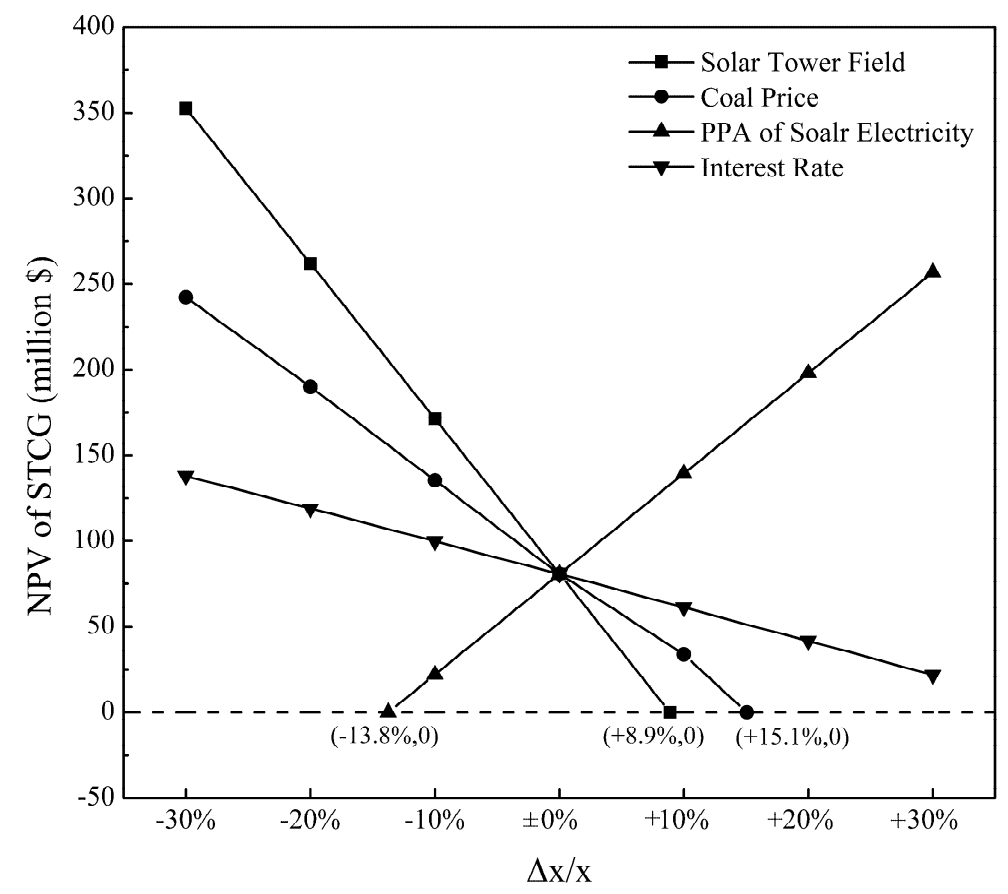

Figure 9. Effect on NPV of a STCG plant by different factors.

Figure 10 shows the effect of different factors on IRR for STCG plant. Figure 10 shows that if the capital cost of the solar tower field increases by $8.9 \%$ (or the coal price increases by $15.1 \%$ or PPA price of solar electricity decreases by $13.8 \%$ ), the IRR of the project will decrease to $8 \%$, which is the same to the benchmark yield. If the capital cost of the solar tower field or coal price further increases, or the PPA price of solar electricity further decreases, the project will suffer losses. The interest rate of debt has less effect on IRR as IRR is always higher than $8 \%$ (the benchmark yield) when the interest rate changes within a $\pm 30 \%$ range.

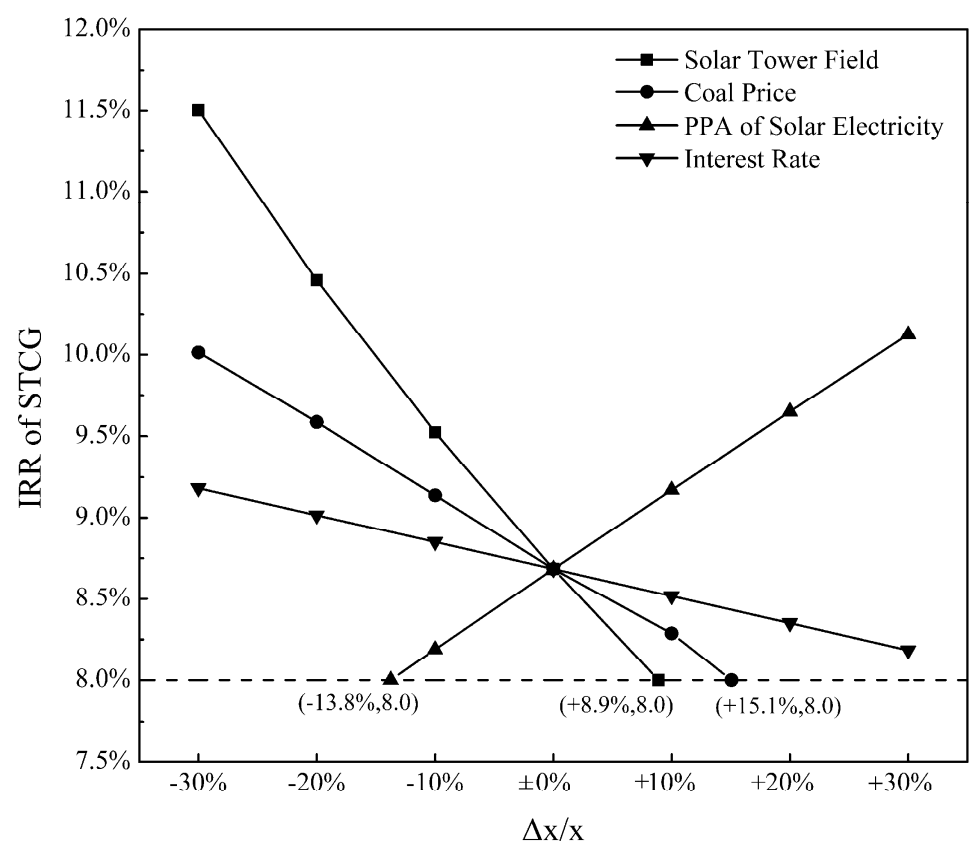

Figure 10. Effect of different factors on IRR for a STCG plant. 
Figures 8-10 show that main impact factors (pay-back period, NPV, IRR) can be ranked in order of sensitivity as: capital cost of the solar tower field, PPA price of solar electricity, coal price, and interest rate of debt.

Table 5 shows variation trends of the main impact factors (pay-back period, NPV, IRR) with every $10 \%$ increases of external factors (capital cost of the solar tower field, PPA price of solar electricity, coal price, and the interest rate of debt). When an external factor changes, the rest are kept unchanged. What should be noted is that the values in the table are relative to the values when $\Delta x / x=0$ in Figures 8-10. In other words, when an external factor (for example coal price) increases by $10 \%$, the changed value (for example NPV) is obtained, dividing the NPV when all external factors are kept unchanged.

Table 5. Variation trends of main impact factors along with the changes of external factors

\begin{tabular}{|c|c|c|c|c|c|}
\hline Impact Factors & & SPP & DPP & NPV & IRR \\
\hline $\begin{array}{l}\text { Capital cost of the solar tower field } \\
\text { PPA price of solar electricity } \\
\text { Coal price } \\
\text { Interest rate of debt }\end{array}$ & $\begin{array}{l}\text { Increase by } \\
10 \% \text { every } \\
\text { time }\end{array}$ & $\begin{array}{l}+5.93 \% \\
-3.48 \% \\
+3.32 \% \\
+1.69 \%\end{array}$ & $\begin{array}{l}+12.33 \% \\
-8.15 \% \\
+7.66 \% \\
+3.24 \%\end{array}$ & $\begin{array}{l}-112.25 \% \\
+72.68 \% \\
-66.2 \% \\
-23.94 \%\end{array}$ & $\begin{array}{c}-10.37 \% \\
+5.59 \% \\
-5.15 \% \\
-1.92 \%\end{array}$ \\
\hline
\end{tabular}

Figure 11 shows the effect on LCOE of STCG by different factors. In Figure 11, with the increase of the capital cost of the solar tower field, coal price, or interest rate of debt, the total cost of a STCG plant project and LCOE will increase. LCOE is not affected by PPA price of solar electricity, due to it being used to measure the cost of per kWh of electricity and is irrelevant for electricity selling revenue. The main impact factors (to LCOE) can be ranked in order of sensitivity as the capital cost of the solar tower field, coal price, and interest rate of debt.

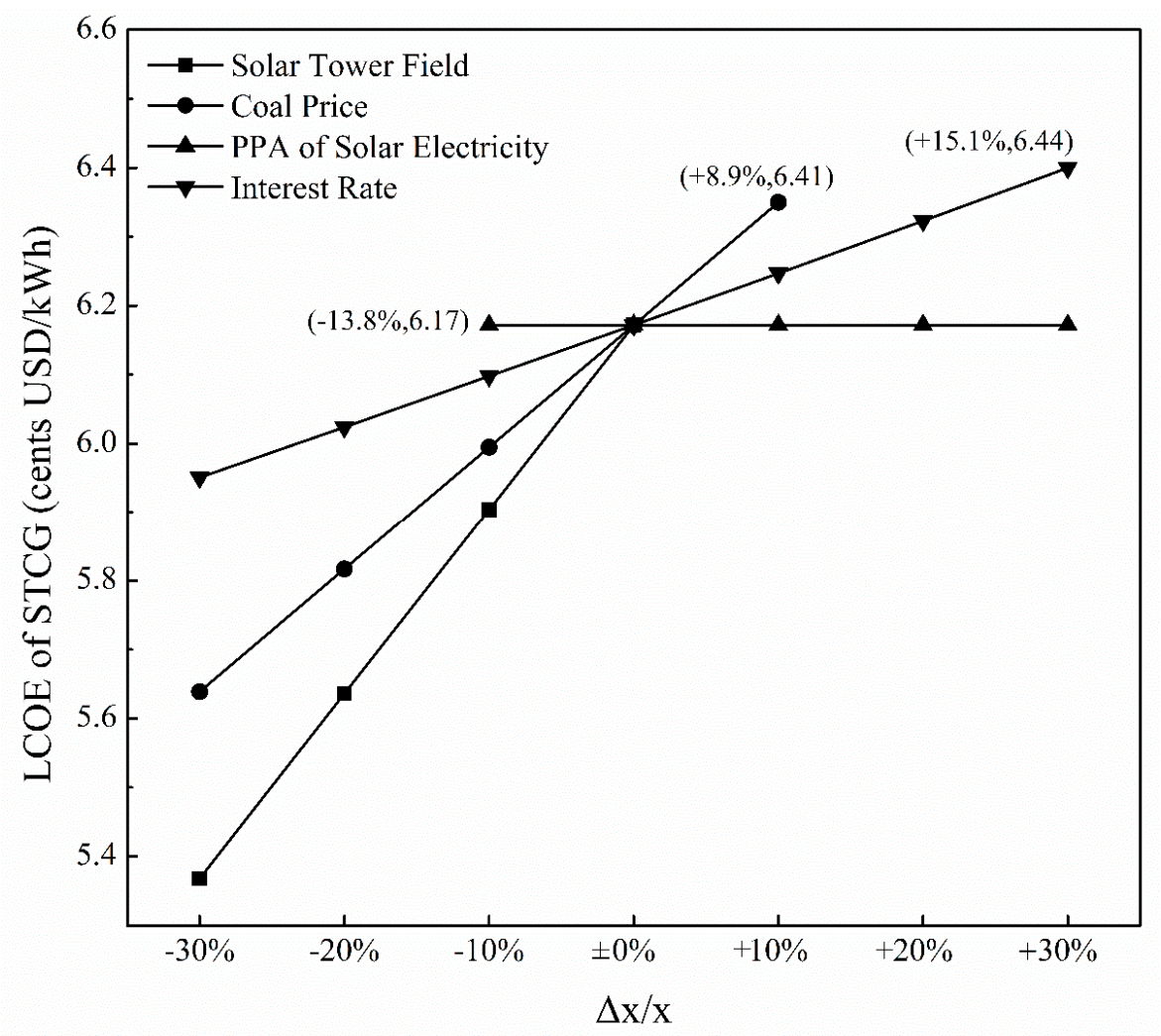

Figure 11. Effect of different factors on LCOE for STCG plant. 
The sensitivity analysis above shows that the decrease of the capital cost of the solar tower field, coal price, and interest rate, or the increase of PPA price of solar electricity is beneficial for cost recovery and obtaining more profits. It is expected that as solar tower power generation technology becomes more developed, the capital cost of the solar tower field and PPA price of solar electricity will decrease gradually. The effect of the two factors on the main assessment indicators are opposite to each other. The capital cost of the solar tower field has greater effect on the main indicators than PPA price of solar electricity. This is due to the fact that capital cost of the solar tower field accounts for more than $60 \%(\mathrm{SM}=2.5)$ in the total capital cost a STCG plant project. Coal prices change according to the coal market, but have little effect on the project because of the coal-electricity price linkage policy. Although the interest rate of debt has less effect on the main indicators than the other three factors (i.e., the capital cost of the solar tower field, coal price, PPA price of solar electricity), it is an important factor that cannot be ignored. Therefore, low interest debt (3\%) from the Asian Development Bank is beneficial to gaining more profits from a plant project [53].

\subsection{Policy-Making Proposals}

Compared with CPG systems, STCG can enhance utilization efficiency while decreasing the generating cost of solar energy, reducing coal consumption and $\mathrm{CO}_{2}$ emissions, as well as decreasing the cost of carbon capture. However, the LCOE of STCG is higher than that of CPG for the same plant size due to the high investment of the solar tower field.

As it can be observed from Figure 12a, the increase on solar tower field cost (from $-30 \%$ to $8.9 \%$ ) is translated into LCOE differences of 1.67 to 2.71 cents USD/kWh higher for STCG. In the case of considering coal price changes (from $-30 \%$ to $15.05 \%$ ), there is an LCOE change of 2.54 to 2.44 cents USD $/ \mathrm{kWh}$ for STCG as it is observed in Figure 12b. In the case of considering interest rate changes on the range of $-30 \%$ to $30 \%$, the LCOE of STCG is higher than that of CPG by 2.33 to 2.61 cents USD/kWh (Figure 12c). While changes on PPA of solar electricity do not have an effect on LCOE for STCG or CPG cases, and therefore the LCOE of STCG is always higher than that of CPG by 2.47 cents $\mathrm{USD} / \mathrm{kWh}$.

In order to promote STCG technology deployment and coal consumption reduction and its associated $\mathrm{CO}_{2}$ emissions, plant owners should get an allowance equivalent to the LCOE price difference between STCG and CPG. From the analysis above, when external influencing factors (coal price, solar tower field price, interest rate, or PPA of solar electricity) change on a range of $\pm 30 \%$, LCOE of STCG is always higher than that of CPG in a range of 1.67 to 2.71 cents USD/kWh. In order to reduce the distances between CPG and STCG technologies, partial or total price difference should be covered by the introduction of solar subsidies. Apart from the cost of electricity generation on STCG plants, there is another aspect to be considered, and it is about the $\mathrm{CO}_{2}$ emissions, for the case of the CPG reference plant, these are of 110 million tons per year, while for the case of STCG plant they are reduced to 97 million tons per year (calculated considering real coal [29]). Resulting in a saved 13 million tons of $\mathrm{CO}_{2}$ emissions which translates into an important reduction on carbon capture costs [54-56] for the STCG of 0.48 cents USD/kWh compared to the CPG plant. In this case, LCOE subsidies could be lowered to the order of 1.18 to 2.22 cents USD/kWh for the STCG plant depending on different external factors scenarios or about 1.99 cents USD/kWh without any other factor contribution. 


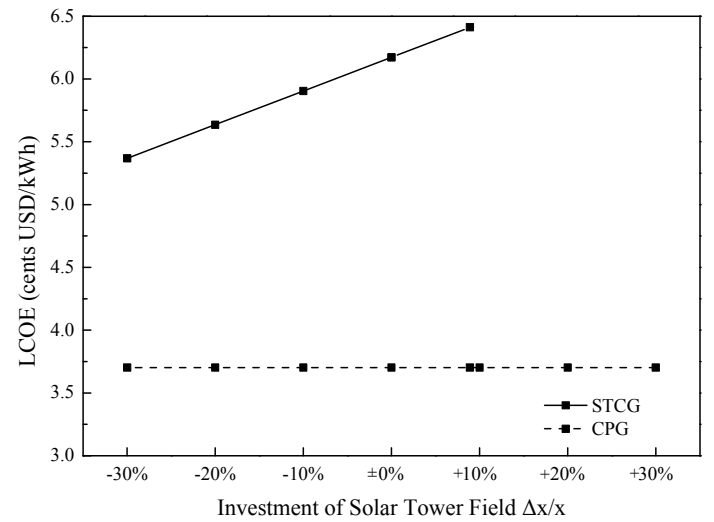

(a) Effect of investment of solar tower field on LCOE

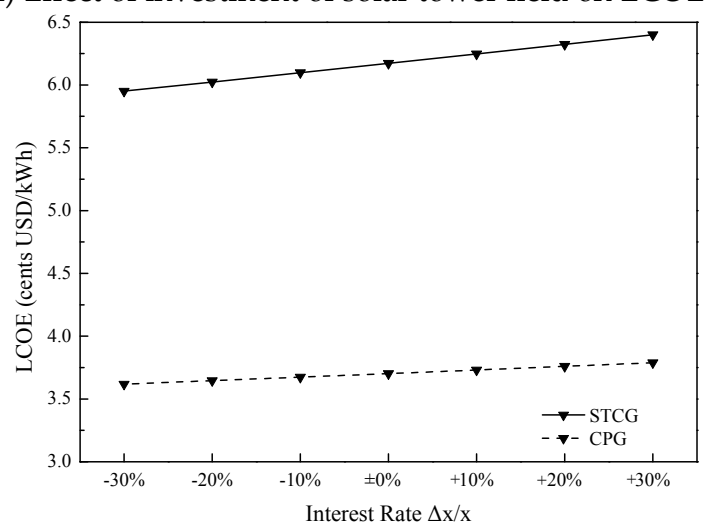

(c) Effect of interest rate on LCOE

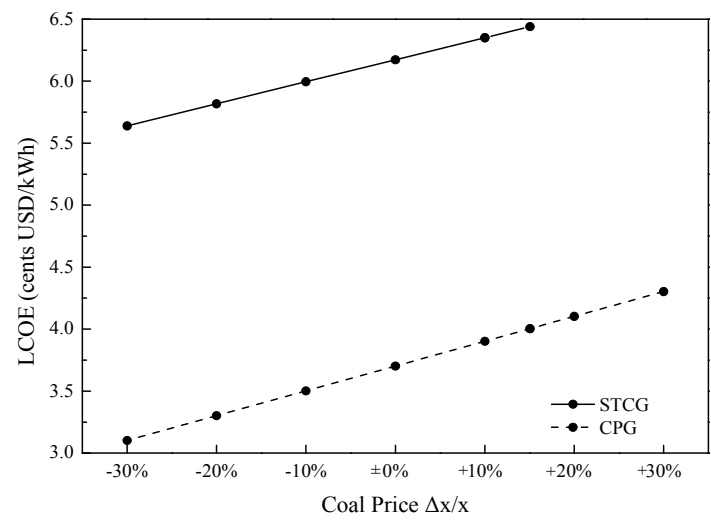

(b) Effect of coal price on LCOE

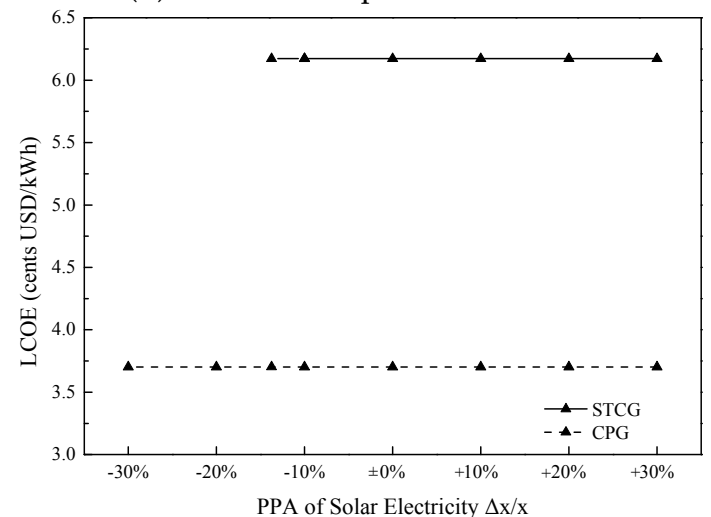

(d) Effect of PPA of solar electricity of LCOE

Figure 12. Comparisons between LCOE of STCG and CPG.

\section{Conclusions}

In this paper, technical and economic characteristics of 1000 MWe STCG plant project are analyzed. Some conclusions about power output, financial conditions, and profits and losses of the project are as follows:

(1) In the life cycle of a STCG plant project, $1.36 \times 10^{5}$ GWh electricity can be generated with selling revenue of USD 9.4 billion. SPP and DPP of the project are 12.2 years and 23.5 years (including construction period) respectively. NPV of the project is USD 80.7 million, IRR of the project is $8.7 \%$, and LCOE of the project is $0.062 \mathrm{USD} / \mathrm{kWh}$, indicating a good profitability.

(2) When solar multiple of STCG increases from 1.0 to 2.5, SPP and DPP of the project will be lengthened by 2.8 years and 9.5 years respectively, NPV and IRR will decrease by $77.5 \%$ and $31.2 \%$ respectively, and LCOE of the project will increase by $33.0 \%$. The results indicate that the capital cost of the solar tower field is the key factor for more profits from the project.

(3) The effect of the capital cost of the solar tower field, PPA price of solar electricity, coal price, and interest rate of debt on the main indicators (i.e., pay-back period, NPV, IRR) will be gradually decreased. In order to ensure project profits, it is better to develop technology for solar tower power generation and acquire low interest debt so as to offset the effect of the decrease of electricity price and the increase of coal price.

(4) Solar tower aided coal-fired power plant (STCG plant) will increase the LCOE; and meanwhile will contribute on carbon capture price reduction of coal-fired power plant. In this case, an STCG plant will need an allowance of 1.99 cents USD/kWh as generation policy.

Acknowledgments: We are grateful for the Program for National Basic Research Program of China-973 Project (No. 2015CB251505), National Natural Science Foundation of China (No. 51106048), and National High-tech R\&D 
Program of China (863 Program) (2012AA050604); Supported by the Fundamental Research Funds for the Central Universities is also highly appreciated. The authors would like to thank "Comunidad De Madrid" for its support to the ALCCONES project (S2013/MAE-2985) through the Program of R\&D activities between research groups in Technologies 2103, co-financed by structural funds.

Author Contributions: Yong Zhu conceived and built the models of related systems; Yong Zhu and Rongrong Zhai calculated and analyzed financial data together; Yong Zhu, Yongping Yang and Miguel Angel Reyes-Belmonte wrote the manuscript, Yong Zhu, Rongrong Zhai and Miguel Angel Reyes-Belmonte revised the manuscript; and Miguel Angel Reyes-Belmonte helped in English modification. All authors agreed on the final version of the manuscript.

Conflicts of Interest: The authors declare no conflict of interest.

\section{Nomenclature}

\begin{tabular}{|c|c|}
\hline \multicolumn{2}{|c|}{ Abbreviations } \\
\hline CNY & Chinese currency \\
\hline CPG & coal-fired power generation system \\
\hline DNI & direct normal irradiance \\
\hline DPP & dynamic pay-back period \\
\hline DSCR & debt service coverage ratio \\
\hline EPC & engineering procurement construction \\
\hline IRR & internal rate of return \\
\hline $\mathrm{LCOE}$ & levelized cost of electricity \\
\hline LHV & lower heating value \\
\hline NPV & net present value \\
\hline O\&M & operation and maintenance \\
\hline PPA & power purchase agreement \\
\hline ROE & rate of return on common stock holders' equity \\
\hline ROI & return on investment \\
\hline SM & solar multiple \\
\hline SPP & static pay-back period \\
\hline STCG & solar tower aided coal-fired power generation system \\
\hline STG & solar tower power generation system \\
\hline USD & United States Dollar \\
\hline VAT & value-added tax \\
\hline \multicolumn{2}{|c|}{ Mathematical Symbols } \\
\hline BY & benchmark yield (\%) \\
\hline$C_{\Delta}$ & $\begin{array}{l}\text { changed price after considering the coefficient of co-movement at the last stage } \\
(\mathrm{CNY} / \mathrm{t})\end{array}$ \\
\hline$C_{\text {cap }}$ & O\&M cost per kW electricity in $C_{\text {gen }}$ each year (USD/kW-y) \\
\hline$C_{\text {gen }}$ & O\&M cost per unit power generation (USD/kWh) \\
\hline$C I_{n}$ & cash inflow (USD) \\
\hline$C_{i}$ & standard coal consumption rate at the last stage $(\mathrm{g} / \mathrm{kWh})$ \\
\hline$C_{n}$ & annual net cash flows in the nth year (USD) \\
\hline $\operatorname{Cost}_{n}$ & annual cost in the nth year (USD) \\
\hline $\operatorname{Cost}_{\mathrm{ann}, n}$ & annual cost in the nth year (from the first year) (USD) \\
\hline $\mathrm{CO}_{n}$ & cash outflow (USD) \\
\hline$D_{n-1}$ & remaining debt by the end of the ( $n-1)$ th year (USD) \\
\hline EBIT & annual profit of the project (USD) \\
\hline $\mathrm{EC}$ & total capital of the project (USD) \\
\hline$I_{\mathrm{CC}}$ & capital cost of STCG (USD) \\
\hline$I_{\mathrm{DCC}}$ & direct capital cost of STCG (USD) \\
\hline$I_{\text {ele }}$ & total electricity revenue of a STCG plant in full life cycle (USD) \\
\hline$I_{\mathrm{ICC}}$ & indirect capital cost of STCG (USD) \\
\hline$I_{\mathrm{int}, n}$ & interest of debt in the nth year (USD) \\
\hline
\end{tabular}




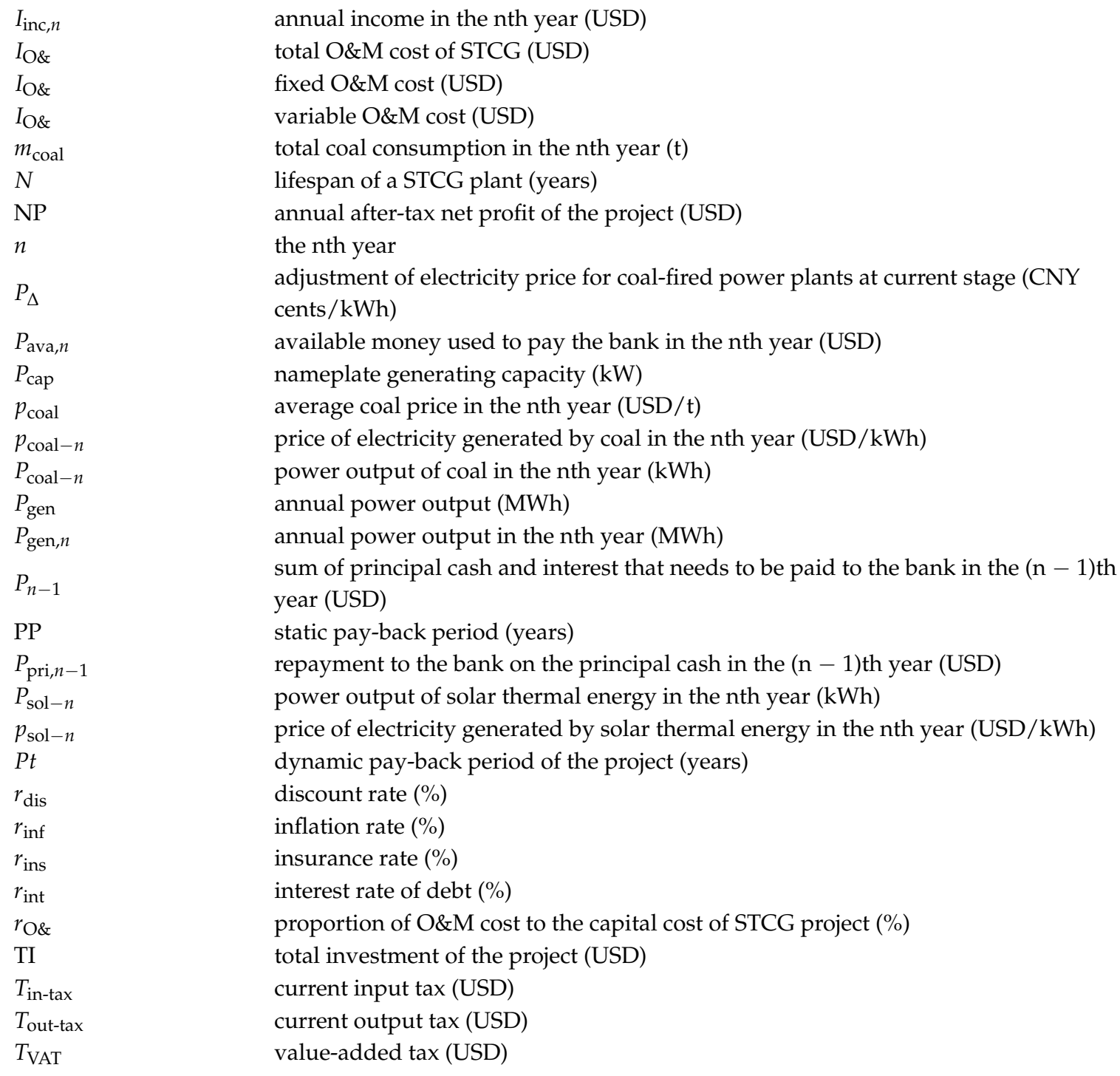

\section{References}

1. China Electricity Council. Available online: http://www.cec.org.cn/guihuayutongji/tongjxinxi/niandushuju/ 2015-11-30/146012.html (accessed on 3 September 2017). (In Chinese)

2. Yang, Y.; Guo, X.; Wang, N. Power generation from pulverized coal in China. Energy 2010, 35, 4336-4348. [CrossRef]

3. Recommendations for the 13th Five-Year Plan for Economic and Social Development of the People's Republic of China. Available online: http:/ / www.gov.cn/xinwen/2015-11/03/content_5004093.htm (accessed on 3 September 2017). (In Chinese)

4. Reddy, V.S.; Kaushik, S.C.; Ranjan, K.R.; Tyagi, S.K. State-of-the-art of solar thermal power plants-A review. Renew. Sustain. Energy Rev. 2013, 27, 258-273. [CrossRef]

5. Guédez, R.; Spelling, J.; Laumert, B.; Fransson, T. Optimization of thermal energy storage integration strategies for peak power production by concentrating solar power plants. Energy Procedia 2014, 49, 1642-1651. [CrossRef]

6. Reyes-Belmonte, M.A.; Sebastián, A.; Romero, M.; González-Aguilar, J. Optimization of a recompression supercritical carbon dioxide cycle for an innovative central receiver solar power plant. Energy 2016, 112, 17-27. [CrossRef]

7. Boukelia, T.E.; Mecibah, M.S.; Kumar, B.N.; Reddy, K.S. Investigation of solar parabolic trough power plants with and without integrated TES (thermal energy storage) and FBS (fuel backup system) using thermic oil and solar salt. Energy 2015, 88, 292-303. [CrossRef] 
8. International Renewable Energy Agency (IRENA). Renewable Energy Technologies: Cost Analysis Series-Concentrating Solar Power. Volume 1: Power Sector Issue 2/5. Available online: http:/ /www.irena. org/home/index.aspx?PriMenuID=12\&mnu=Pri (accessed on 1 June 2012).

9. Hu, E.; Yang, Y.; Nishimura, A.; Yilmaz, F.; Kouzani, A. Solar thermal aided power generation. Appl. Energy 2010, 87, 2881-2885. [CrossRef]

10. Peng, S.; Hong, H.; Wang, Y.; Wang, Z.; Jin, H. Off-design thermodynamic performances on typical days of a $330 \mathrm{MW}$ solar aided coal-fired power plant in China. Appl. Energy 2014, 130, 500-509. [CrossRef]

11. Hou, H.J.; Yu, Z.Y.; Yang, Y.P.; Chen, S.; Luo, N.; Wu, J.J. Performance evaluation of solar aided feedwater heating of coal-fired power generation (SAFHCPG) system under different operating conditions. Appl. Energy 2013, 112, 710-718.

12. Li, Q.; Bai, F.; Yang, B.; Wang, Z.; El Hefni, B.; Liu, S.; Kubo, S.; Kiriki, H.; Han, M. Dynamic simulation and experimental validation of an open air receiver and a thermal energy storage system for solar thermal power plant. Appl. Energy 2016, 178, 281-293. [CrossRef]

13. National Development and Reform Commission. Available online: http://www.sdpc.gov.cn/zcfb/zcfbtz/ 201607/t20160706_810652.html (accessed on 3 September 2017). (In Chinese)

14. Zoschak, R.J.; Wu, S.F. Studies of the direct input of solar energy to a fossil-fueled central station steam power plant. Sol. Energy 1975, 17, 297-305. [CrossRef]

15. Ying, Y.; Hu, E.J. Thermodynamic advantages of using solar energy in the regenerative Rankine power plant. Appl. Therm. Eng. 1999, 19, 1173-1180. [CrossRef]

16. You, Y.; Hu, E.J. A medium-temperature solar thermal power system and its efficiency optimisation. Appl. Therm. Eng. 2002, 22, 357-364. [CrossRef]

17. Yang, Y.; Cui, Y.; Hou, H.; Guo, X.; Yang, Z.; Wang, N. Research on solar aided coal-fired power generation system and performance analysis. Sci. China Ser. E Technol. Sci. 2008, 51, 1211-1221. [CrossRef]

18. Yang, Y.; Yan, Q.; Zhai, R.; Kouzani, A.; Hu, E. An efficient way to use medium-or-low temperature solar heat for power generation-integration into conventional power plant. Appl. Therm. Eng. 2011, 31, 157-162. [CrossRef]

19. Zhai, R.; Zhu, Y.; Yang, Y.; Tan, K.; Hu, E. Exergetic and parametric study of a solar aided coal-fired power plant. Entropy 2013, 15, 1014-1034. [CrossRef]

20. Zhai, R.; Peng, P.; Yang, Y.; Zhao, M. Optimization study of integration strategies in solar aided coal-fired power generation system. Renew. Energy 2014, 68, 80-86. [CrossRef]

21. Zhai, R.; Zhao, M.; Tan, K.; Yang, Y. Optimizing operation of a solar-aided coal-fired power system based on the solar contribution evaluation method. Appl. Energy 2015, 146, 328-334. [CrossRef]

22. Suresh, M.; Reddy, K.S.; Kolar, A.K. 4-E (Energy, Exergy, Environment, and Economic) analysis of solar thermal aided coal-fired power plants. Energy Sustain. Dev. 2010, 14, 267-279. [CrossRef]

23. Zhai, R.; Liu, H.; Li, C.; Zhao, M.; Yang, Y. Analysis of a solar-aided coal-fired power generation system based on thermo-economic structural theory. Energy 2016, 102, 375-387. [CrossRef]

24. Feng, L.; Chen, H.; Zhou, Y.; Zhang, S.; Yang, T.; An, L. The development of a thermo-economic evaluation method for solar aided power generation. Energy Convers. Manag. 2016, 116, 112-119. [CrossRef]

25. Wang, F.; Li, H.; Zhao, J.; Deng, S.; Yan, J. Technical and economic analysis of integrating low-medium temperature solar energy into power plant. Energy Convers. Manag. 2016, 112, 459-469. [CrossRef]

26. Liu, L.; Zhao, J.; Deng, S.; An, Q. A technical and economic study on solar-assisted ammonia-based post-combustion $\mathrm{CO}_{2}$ capture of power plant. Appl. Therm. Eng. 2016, 102, 412-422. [CrossRef]

27. Ozturk, M.; Dincer, I. Thermodynamic assessment of an integrated solar power tower and coal gasification system for multi-generation purposes. Energy Convers. Manag. 2013, 76, 1061-1072. [CrossRef]

28. Zhang, M.; Du, X.; Pang, L.; Xu, C.; Yang, L. Performance of double source boiler with coal-fired and solar power tower heat for supercritical power generating unit. Energy 2016, 104, 64-75. [CrossRef]

29. Zhu, Y.; Zhai, R.; Peng, H.; Yang, Y. Exergy destruction analysis of solar tower aided coal-fired power generation system using exergy and advanced exergetic methods. Appl. Therm. Eng. 2016, 108, 339-346. [CrossRef]

30. Zhai, R.; Yang, Y.; Zhu, Y.; Chen, D. The evaluation of solar contribution in solar aided coal-fired power plant. Int. J. Photoenergy 2013, 15, 5707-5719. [CrossRef]

31. Zhu, Y.; Zhai, R.; Zhao, M.; Yang, Y.; Yan, Q. Evaluation methods of solar contribution in solar aided coal-fired power generation system. Energy Convers. Manag. 2015, 102, 209-2016. [CrossRef]

32. Chen, W. Research on Electricity on-Grid Pricing Mechanisms in China; Xiamen University: Xiamen, China, 2017. (In Chinese) 
33. China Electricity Council. Available online: http://www.cec.org.cn/ (accessed on 3 September 2017). (In Chinese)

34. Bank, T.W. Assessment of Technology Options for Development of Concentrating Solar Power in South Africa for The World Bank. Available online: www.worldbank.org/ (accessed on 10 October 2010).

35. Electric Power Planning \& Engineering Institute. Reference Cost Index of Limitation Design of Thermal Power Projects; China Electric Power Press: Beijing, China, 2015; ISBN 9787512377875. (In Chinese)

36. China Inflation Rate. Available online: http://www.tradingeconomics.com/china/inflation-cpi (accessed on 3 September 2017). (In Chinese)

37. Duan, L.; Xia, K.; Feng, T.; Jia, S.; Bian, J. Study on coal-fired power plant with $\mathrm{CO}_{2}$ capture by integrating molten carbonate fuel cell system. Energy 2016, 117, 578-589. [CrossRef]

38. Viebahn, P.; Kronshage, S.; Lechon, Y. Deliverable n 12.2-RS Ia" Final Report on Technical Data, Costs, and Life Cycle Inventories of Solar Thermal Power Plants; New Energy Externalities Developments for Sustainability (NEEDS) Integrated Project; European Commission: Brussels, Belgium, 2008.

39. System Advisor Model. Available online: https:/ / sam.nrel.gov/ (accessed on 3 September 2017).

40. Hearps, P.; McConnell, D. Renewable Energy Technology Cost Review; Melbourne Energy Institute: Melbourne, Australia, 2011; pp. 1-58.

41. Short, W.; Packey, D.J.; Holt, T. A Manual for the Economic Evaluation of Energy Efficiency and Renewable Energy Technologies; University Press of the Pacific: Honolulu, HI, USA, 2005.

42. Wang, X.; Kurdgelashvili, L.; Byrne, J.; Barnett, A. The value of module efficiency in lowering the levelized cost of energy of photovoltaic systems. Renew. Sustain. Energy Rev. 2011, 15, 4248-4254. [CrossRef]

43. Hernández-Moro, J.; Martínez-Duart, J.M. Analytical model for solar PV and CSP electricity costs: Present LCOE values and their future evolution. Renew. Sustain. Energy Rev. 2013, 20, 119-132. [CrossRef]

44. Zhao, Y.; Hong, H.; Jin, H. Optimization of the solar field size for the solar-coal hybrid system. Appl. Energy 2017, 185, 1162-1172. [CrossRef]

45. Bank of China. Available online: http://www.boc.cn/fimarkets/lilv/fd32/201510/t20151023_5824975.html (accessed on 3 September 2017). (In Chinese)

46. Weather Data of System Advisor Model. Available online: https://sam.nrel.gov/weather/ (accessed on 3 September 2017).

47. STEAG Energy Services GmbH—System Technologies. Available online: http:/ / www.steag-systemtechnologies. com/ (accessed on 3 September 2017).

48. Zhu, Y.; Zhai, R.; Qi, J.; Yang, Y.; Reyes-Belmonte, M.A.; Romero, M.; Yan, Q. Annual performance of solar tower aided coal-fired power generation system. Energy 2017, 119, 662-674. [CrossRef]

49. Kolb, G.J.; Ho, C.K.; Mancini, T.R.; Gary, J.A. Power Tower Technology Roadmap and Cost Reduction Plan; SAND2011-2419; Sandia National Laboratories: Albuquerque, NM, USA, 2011.

50. Zhao, Y.; Hong, H.; Jin, H. Appropriate feed-in tariff of solar-coal hybrid power plant for China's Inner Mongolia Region. Appl. Therm. Eng. 2016, 108, 378-387. [CrossRef]

51. Zhejiang Supcon Solar Technology Co., LTD. Available online: http:/ / www.supconsolar.com/view.asp?id=78 (accessed on 3 September 2017). (In Chinese)

52. National Development and Reform Commission. Available online: http://www.sdpc.gov.cn/fzgggz/jggl/ zcfg/201512/t20151231_770457.html (accessed on 3 September 2017). (In Chinese)

53. Asian Development Bank. 2014 Annual Report. Available online: http://www.adb.org/documents/adbannual-report-2014 (accessed on 3 September 2017).

54. Xu, G.; Hu, Y.; Tang, B.; Yang, Y.; Zhang, K.; Liu, W. Integration of the steam cycle and $\mathrm{CO}_{2}$ capture process in a decarbonization power plant. Appl. Therm. Eng. 2014, 73, 277-286. [CrossRef]

55. Yu, S.; Zhang, J.; Cheng, J. Carbon reduction cost estimating of Chinese coal-fired power generation units: A perspective from national energy consumption standard. J. Clean. Prod. 2016, 139, 612-621. [CrossRef]

56. Black, J. Cost and Performance Baseline for Fossil Energy Plants Volume 1: Bituminous Coal and Natural Gas to Electricity; National Energy Technology Laboratory: Washington, DC, USA, 2010.

(C) 2017 by the authors. Licensee MDPI, Basel, Switzerland. This article is an open access article distributed under the terms and conditions of the Creative Commons Attribution (CC BY) license (http:/ / creativecommons.org/licenses/by/4.0/). 